\title{
THE SLOVENIAN TERRITORY AS A BORDERLAND IN THE MIDDLE AGES
}

\begin{abstract}
The geographic location between the Adriatic Sea, the Alps, the Pannonian Plain and the Balkan Peninsula has made the territory of present-day Slovenia an important transitional area from prehistory onwards. This especially concerns a route between the Apennine Peninsula, and central and eastern or south-eastern Europe. This strategically important borderland has been at the crossroads of cultures, peoples, nations and languages. It witnessed incursions of the Goths, Huns and Langobards to Italy, collisions of Frankish, Avar and Byzantine interests, the settling of the Slavs and Hungarian raids to Italy. The German Kingdom, later Holy Roman Empire, established a defence system of border provinces at its south-eastern corner where feudal families, dynasts and kingdoms such as Přemysl Otakar II, the Habsburgs and the Counts of Cilli fought for territory, influence and access to the northern Adriatic area controlled by the Venetians. In the $15^{\text {th }}$ and $16^{\text {th }}$ centuries, the area was continuously attacked by the Ottomans. The article outlines some of these events and presents a selection of the extant pieces of arms and armour, of equestrian and horse gear that are kept in Slovenian museums, as well as some archaeological sites important for the problem.
\end{abstract}

Keywords: Slovenia, borderland, peoples, wars, incursions, raids, arms, armour, Late Antiquity, Middle Ages

The geographic location between the Adriatic Sea, the Alps, the Pannonian Plain and the Balkan Peninsula has made the territory of present-day Slovenia an important transitional area from prehistory onwards. In the line from Marseille in France to Thessaloniki in Greece, the easiest land route from west to east, i.e., from the Mediterranean across the Alps and the Dinaric Mountains, led across the Slovenian territory. This route was especially important for the communication between the Apennine Peninsula, blocked to the north by the Alps, and central and eastern or south-eastern Europe. It was of vital importance for the Roman Empire. Later in the Middle Ages, this southeastern corner of the German Holy Roman Empire was the area where four spheres met: the Romanic with Venice and Aquileia to the southwest, the Hungarian to the northeast, the Germanic with Salzburg, Vienna and other centres to the north and northwest, and the Slavic to the east and southeast. Throughout centuries, the Slovenian territory has been at the crossroads of cultures, peoples, nations and languages.

The military history of this strategically important borderland was influenced by various geographic, cultural, ethnic and political circumstances. Late Antiquity, the period

\footnotetext{
* National Museum of Slovenia, Ljubljana, tomaz.nabergoj@nms.si
}

of a gradual decline of the Roman Empire and the spread of Christianity when the eastern border of Italy was protected by the Alpine defence system, witnessed incursions of the Goths, Huns and Langobards to Italy. In the Early Middle Ages, the interests of the Franks collided with those of the Byzantines in this area. It also witnessed a gradual settlement of the Slavs, bordering the Langobards to the west and the Avars to the east. They formed their homeland mostly along the upper Sava Valley. It was probably a principality which the Langobard historiographer Paul the Deacon in the late $8^{\text {th }}$ century named Carniola Sclavorum patria. From the early $9^{\text {th }}$ century onwards, however, the Carniolans had to adopt Christianity and accept the rule of the Franks who eventually destroyed the Avar Khanate. In the first half of the $10^{\text {th }}$ century, the Hungarians often crossed this area to raid Italy. After they had been defeated, the German Kingdom established a defence system of border provinces and introduced a new economic and social system.

In the High and Late Middle Ages, a time that saw the formation of feudal estates, counties and countries, as well as of the rise of towns, major military campaigns affected the region. Some of them had an indirect impact, such as the Mongol raids in the mid- $13^{\text {th }}$ century. Others had a direct influence, for instance the campaigns of Prremysl Otakar II around 1270, the feuds between the Habsburgs and the Counts of Cilli in 1437-1443 and the wars between the 
Fig. 1. Map of Slovenia with marked locations of Ljubljana and the Ljubljanica River. Map Roman Hribar.

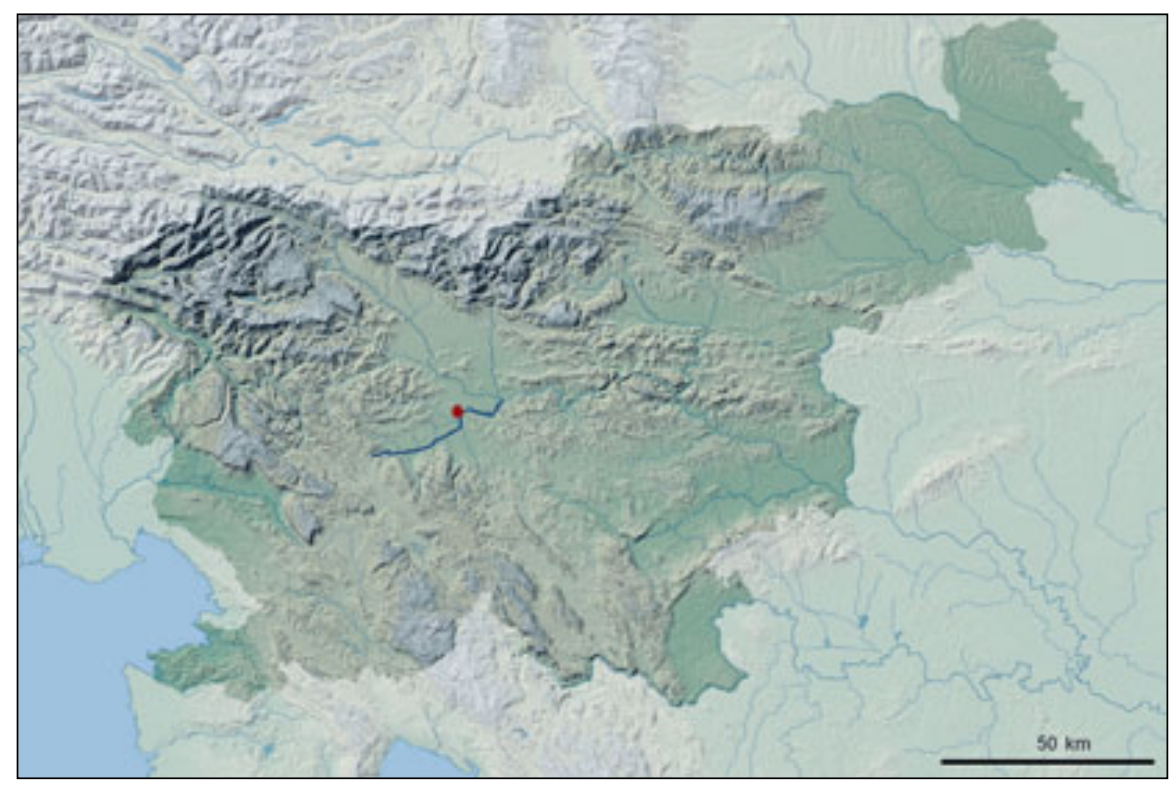

Habsburgs and the Venetians at the end of the Middle Ages (1508-1516) - at the time when the territory of present-day Slovenia became the borderland against the Turks. The text below will outline some of these events and present a selection of the extant objects of arms and armour, of equestrian and horse gear that are kept in Slovenian museums. It will briefly present several important archaeological sites from the medieval period, but also some from Late Antiquity, together with the events that influenced the medieval history of this territory ${ }^{2}$.

The strategic position and features of the landscape define the transitional role of the relatively mountainous territory of Slovenia (Fig. 1). It is where the Pannonian Plain is closest to the Mediterranean Sea and the Karst passes (especially the Postojna Gate) located at altitudes no higher than $606 \mathrm{~m}$ a.s.l. offer a relatively easy passage between the Apennine Peninsula (Italy) and inland regions such as present-day Hungary and Carinthia. In addition, there is the Ljubljanica River, which traverses the marshes of the Ljubljansko barje and flows into the Sava River, which flows into the Danube. It was an important line of communication from prehistory to the Middle Ages and the Early Modern Era. Although only $38 \mathrm{~km}$ long, the Ljubljanica with its deep bed and smooth flow was navigable from its springs near Vrhnika to its confluence into the Sava River. It crossed the marshes southwest of Ljubljana that represented an area of treacherous passage all until the drainage works in the $18^{\text {th }}$ and $19^{\text {th }}$ centuries ${ }^{3}$.

The importance of this connection between the Adriatic and the Black Sea in various epochs from prehistory onwards is reflected in the myth of the Argonauts. According to the variant of the myth written down in the mid- $1^{\text {st }}$

2 Cf. Istenič 2015; Knific and Nabergoj 2016. For a general history of Slovenia cf. Luthar 2013. 2009 century by Pliny the Elder in his Naturalis Historia, Jason and his Argonauts stole the Golden Fleece in Colchis and fled on their ship Argo. They sailed from the Black Sea up the Danube, up the Sava and up a river called Nauportus (today the Ljubljanica). Upon reaching the springs of this river, they dismantled the ship, carried it on foot to the Adriatic coast, reassembled it and sailed back to Greece ${ }^{4}$.

The territory of present-day Slovenia was of immense strategic importance to the Roman Republic and then the Empire, firstly for defending the easy access to northeastern Italy through the Postojna Gate and secondly for enabling military campaigns of the Roman troops eastwards. The Romans conquered this territory in the $2^{\text {nd }}$ and $1^{\text {st }}$ centuries $\mathrm{BC}$ and incorporated it into the Roman Empire, gradually building strongholds and roads, forming coloniae and municipia (colonia Iulia Emona, present-day Ljubljana, was presumably established in AD 14/15) and introducing the Roman culture. One of the most prominent geographic features and topographic markers which were well-known to Greek and Roman writers was Mount Ocra (today Nanos) where a Roman stronghold was located already at the end of the $2^{\text {nd }}$ century $\mathrm{BC}$. In the time of the Marcomannic Wars (from about 166 until 180), a form of military defence organisation was mentioned in 167/168. It was named praetentura Italiae et Alpium or the barrier of Italy and the Alps.

The internal power struggles in the $3^{\text {rd }}$ century, the military campaigns that several armies waged in this territory and the barbarian incursions across the vulnerable eastern border of Italy led the Romans to construct a defence system here in the $4^{\text {th }}$ and $5^{\text {th }}$ centuries (Fig. 2). It consisted of three lines of barrier walls, fortresses and watchtowers, as well as the large fortress of Castra (today Ajdovščina) in the hinterland. The $4^{\text {th }}$ century Roman

4 Cf. Šašel Kos 2009. 

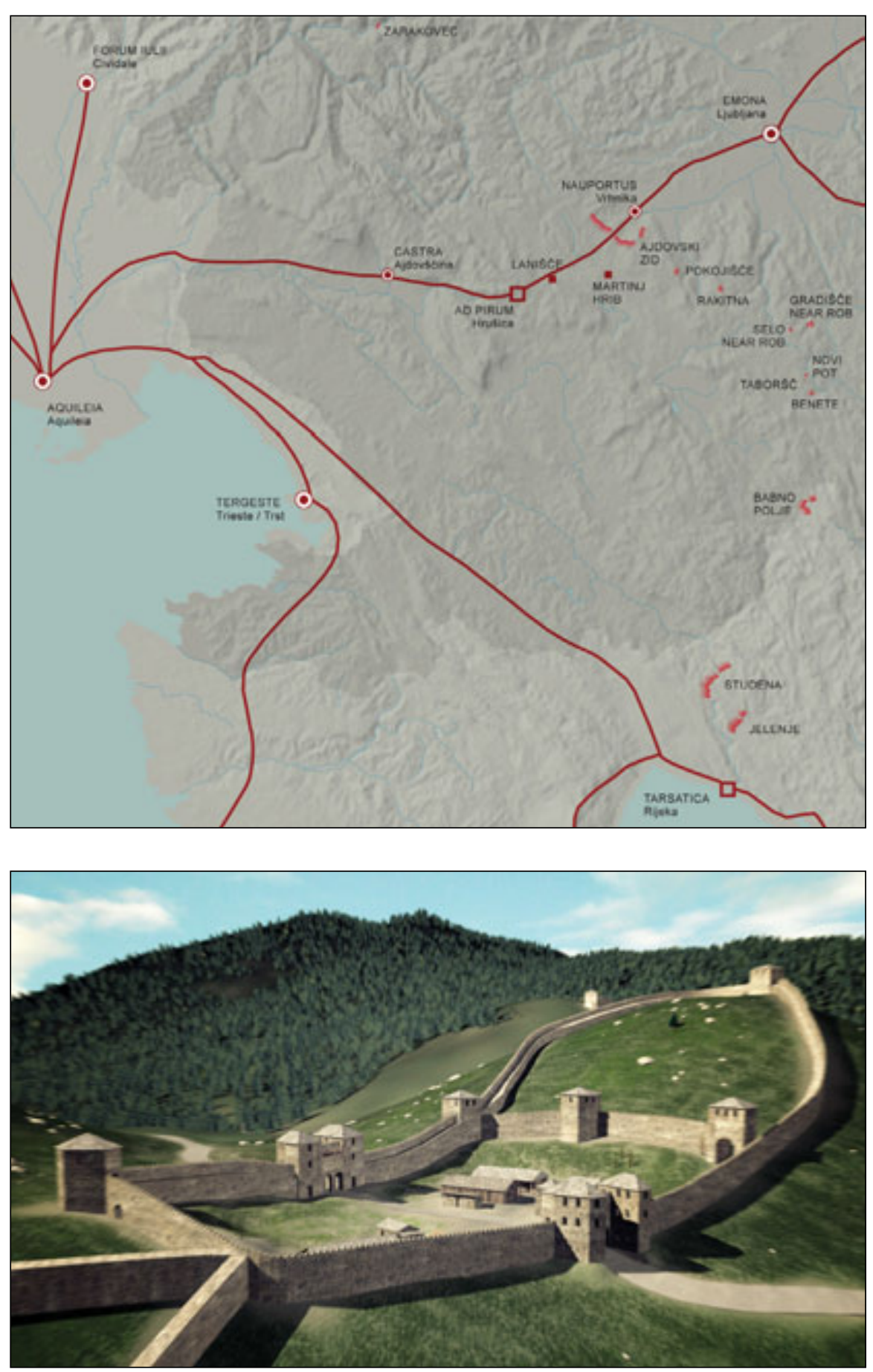

Fig. 2. Map of the Roman defence system of Claustra Alpium Iuliarum with marked sections of the barrier walls, fortresses and the main Roman roads. Map Vida Bitenc - after Istenič 2015, Fig. 171.

Fig. 3. Reconstruction of the Roman fortress of Ad Pirum, Hrušica. Concept Peter Kos, image Igor Dolinar - after Kos 2015, Fig. 308.

historian Ammianus Marcellinus named this defence system claustra Alpium Iuliarum or the Alpine barrier, while the Notitia Dignitatum, a military manual from the early $5^{\text {th }}$ century, called it tractus Italiae circa Alpes or the belt of Italy around the Alps 5 .

One of the fortresses that have been archaeologically investigated and at least partly preserved was called $\mathrm{Ad} \mathrm{Pi-}$ rum, situated at the Hrušica Pass (Fig. 3). It protected the main road to Italy leading from Emona to Aquileia. The fortress was probably built in the last third of the $3^{\text {rd }}$ century and was especially important in the turbulent times of civil wars in the $4^{\text {th }}$ century, for example in 352 when the Roman Emperor Constantius II defeated his rival Emperor Magnentius. The fortress was abandoned at the beginning of the $5^{\text {th }}$ century ${ }^{6}$.

Unfortunately, we have as yet no archaeological traces of the famous Battle of the Fluvius Frigidus that presumably took place somewhere in the upper Vipava Valley. There, on 6 September 394 the Roman army led by Emperor Theodosius I defeated the troops of the pagan usurper Eugenius. This led to a reunification of the Empire and above all marked a decline of pagan traditions. It must have 


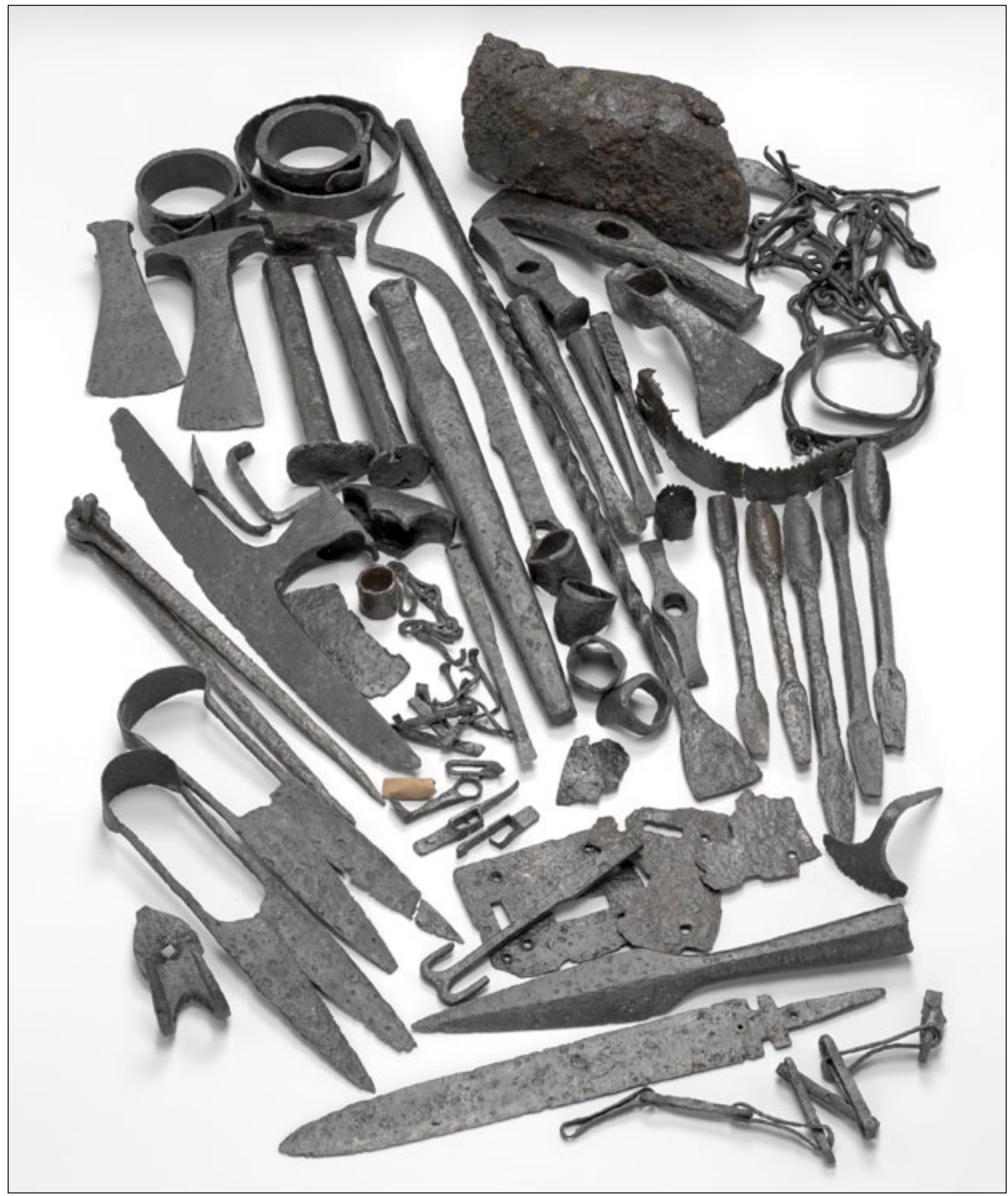

Fig. 4. Hoard from Limberk, around 400, kept in the National Museum of Slovenia. Photo Tomaž Lauko.

been the greatest battle fought in the Slovenian territory in Antiquity.

The instability of the period is mirrored in a hoard find from Limberk near Velika Račna (south-eastern Slovenia), dated to around 400, which contained over 70 iron objects, mostly tools, fittings and weapons (Fig. 4). Among them was also a short sword with notches on the hilt, a weapon attributed to Iranian Alans serving as Roman foederati in Pannonia?.

Incursions of barbarian troops and migrations of peoples to 'the promised land' of Italy forced the indigenous

7 Knific and Nabergoj 2016, 12-13, Fig. 4. 


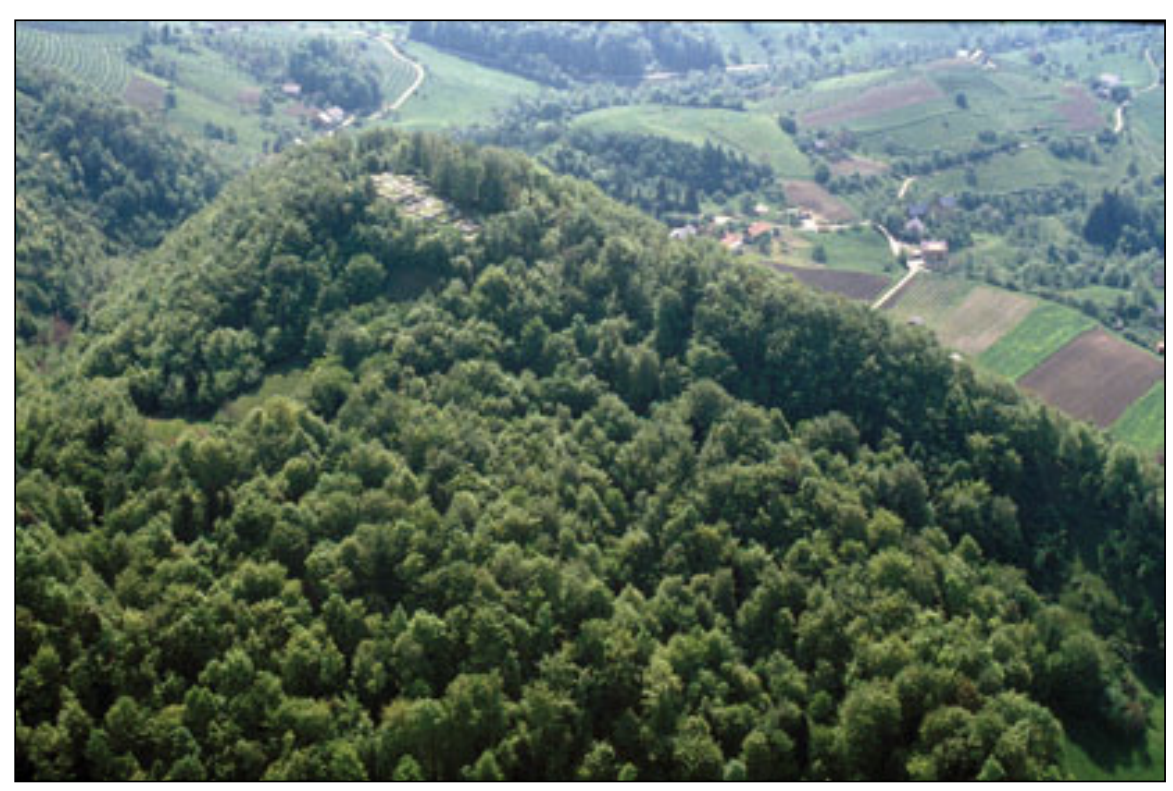

Fig. 5. Aerial view of Ajdovski gradec near Vranje. Photo Jože Hanc.
Roman population in the late $5^{\text {th }}$ and $6^{\text {th }}$ centuries to move away from the main routes and build fortified settlements on hilltops. Such a refugium usually consisted of a Christian church (or a group of ecclesiastical buildings) on top of the hill, houses and a water cistern on the slopes below, all enclosed within defensive walls with towers. Some of the best researched settlements of this type are at Ajdna above Potoki (north-western Slovenia), Tonovcov grad near Kobarid (western Slovenia), Ajdovski gradec near Vranje (eastern Slovenia - Fig. 5) and Kučar near Podzemelj (south-eastern Slovenia). Some settlements were also located in naturally protected lowland areas such as river confluences. A good example is civitas Carnium (today Kranj), a very important Late Antique stronghold built on the promontory overlooking the confluence of the Sava and Kokra Rivers.

The movements of troops and peoples in the $5^{\text {th }}$ and $6^{\text {th }}$ centuries included the Visigoths (e.g. in AD 401, 405 and 408), Huns (452), Ostrogoths (489), Langobards (568), as well as Avars and Slavs (end of $6^{\text {th }}$ century). The Visigoths and Huns only crossed the territory on their way to Italy and left almost no archaeological traces (if we exclude unreliable evidence such as a thick layer of ash found during the archaeological excavations of the Early Christian religious centre in Emona (Ljubljana) and sometimes connected with the Hun incursion to Italy in 452). Rare finds of Hun origin presumably include a grave of a nomadic warrior which was excavated at Ptuj (north-eastern Slovenia - Fig. 6). He was buried with a single-edged sword. The analyses of the skeleton with an artificially deformed skull and several mongoloid features as well as marks indicating a warrior with riding skills and using a bow suggest an Asian, probably Hun origin. This is supported by a gilded open-ended earring found at the skull ${ }^{8}$.

8 Knific and Nabergoj 2016, 22-23, Figs. 15-17. Cf. Lubšina Tušek 2004, 76-78.
After the fall of the Western Roman Empire in 476, the territory of present-day Slovenia formed part of two barbarian kingdoms. The first was the Ostrogothic Kingdom (493-c. 540). The Ostrogoths under King Theodoric moved from the Balkans towards Italy in 488. They defeated Odoacer, ruler of Italy, in the battle at the bridge across the Soča River (Pons Sonti, today Majnice near Gorizia, Italy) in 489 and conquered Italy in 493 . The second was the Langobard Kingdom which was initially located in the Pannonian Plain. In 547/548, the Byzantine Emperor Justinian gave the Langobards 'strongholds along the Pannonian border' (ohirómata epi Pannonías) and Pólis Norikón (eastern Slovenia, between the Savinja, Sava and Sotla Rivers). In 568, under King Alboin, they moved to Italy. ${ }^{9}$ Individual characteristically Langobard objects have been found at various Roman hilltop settlements in Slovenia, mostly within important buildings at exposed locations, suggesting that Langobard garrisons controlled these settlements and the nearby communication routes in the mid$6^{\text {th }}$ century. Paul the Deacon in his major work Historia Langobardorum (end of $8^{\text {th }}$ century) described the route the Langobards took on their way to Italy and mentioned that „from the eastern side by which it is joined to Pannonia" Italy had ,,an approach which lies open more broadly and is quite level"10. This most probably refers to the Vipava Valley in western Slovenia.

Having settled in Italy, the Langobards retained the strongholds at the western border of present-day Slovenia and the most important fortress at Carnium (Kranj). In the $6^{\text {th }}$ century this fortress was under the Ostrogoth, then briefly under Byzantine and later under Langobard rule. Until the beginning of the $7^{\text {th }}$ century it controlled access to Langobard Italy from the north. The Langobard presence in

\footnotetext{
9 Ciglenečki 1992; Knific and Nabergoj 2016, 39-40.

10 Foulke 1907, 65.
} 
Fig. 6. Furnishings from the grave of an Asian (probably Hun) warrior, Ptuj, $2^{\text {nd }}$ half of the $5^{\text {th }} c$., kept temporarily at the Institute for the Protection of Cultural Heritage, Regional Office Maribor. Photo Tomaž Lauko.

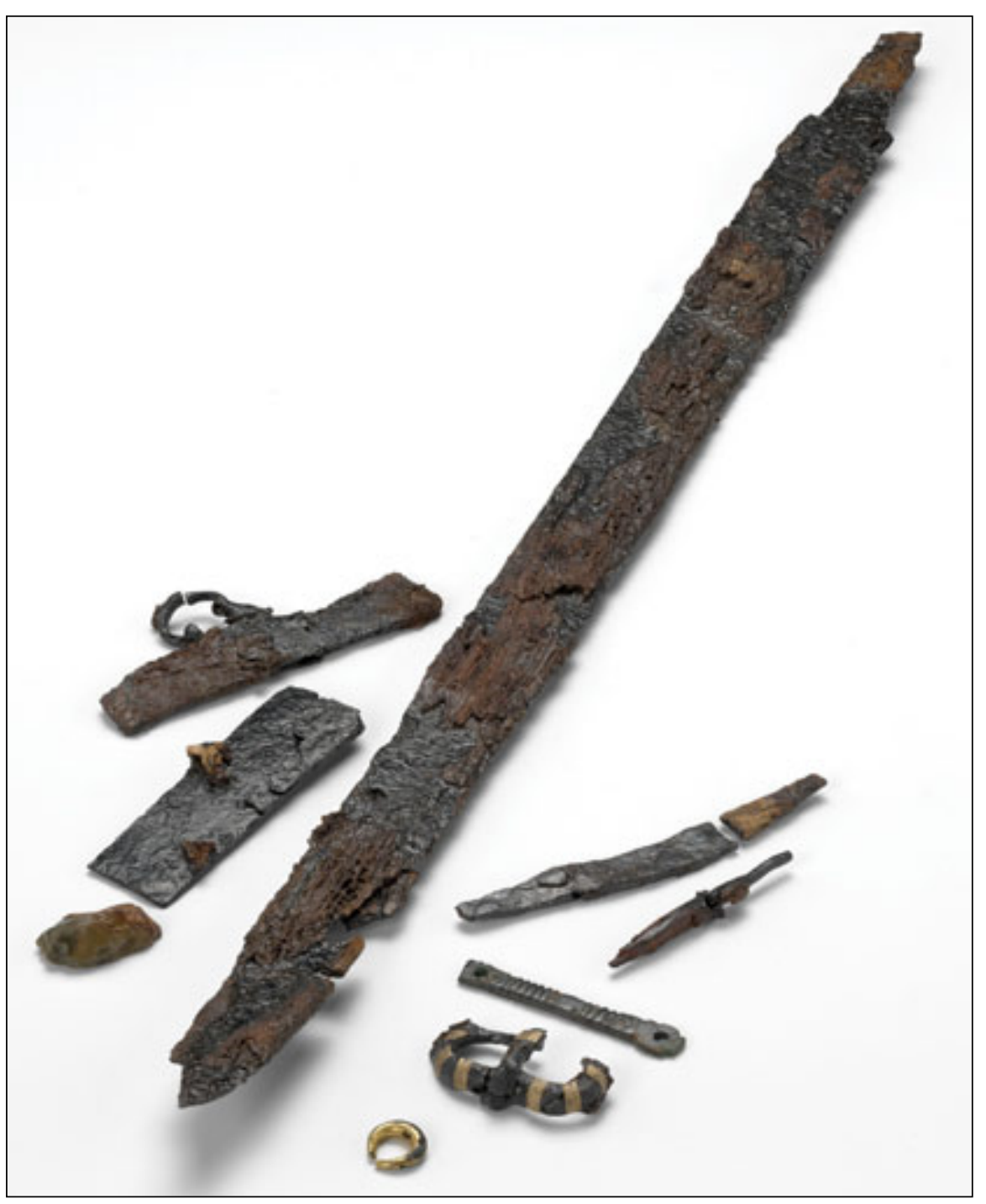

Slovenia is evidenced by finds of weaponry from cemeteries such as that at Solkan near Nova Gorica ${ }^{11}$, though the most important cemetery in this respect is the one at Lajh in $\mathrm{Kranj}^{12}$. This cemetery has thus far revealed some 720 graves containing goods belonging to the mixed population in Carnium: indigenous Romans and Germanic inhabitants, among them Ostrogoths and Langobards, while some artefacts, particularly pieces of jewellery, point to Alamans and Franks (Fig. 7) ${ }^{13}$.

Twenty-one of the graves at Lajh belonged to warriors and contained long double-edged swords, single-edged combat knives (sax), arrowheads, spearheads, battle axes, as well as some shield bosses and hooks for quiver suspen$\operatorname{sion}^{14}$. One of the bowmen was found buried with offensive weaponry exclusively: a sword, 23 arrowheads, a hook for quiver suspension and two combat knives. Some of the arrowheads are trilobate with a pyramidal tip. Such arrowheads that presumably represent Byzantine weaponry were

11 Knific and Svoljšak 1984.

12 Knific 2004.

13 Knific and Nabergoj 2016, 42.

14 Knific and Nabergoj 2016, 41-48. used to penetrate lamellar armour or mail ${ }^{15}$. Another exclusive and very rare find belonging to the military elite was excavated in Kranj in 2005. These were two well preserved lamellar armours dated to the second half of the $6^{\text {th }}$ century (Fig. 8). They were found within the settlement together with a Frankish lance (ango) ${ }^{16}$. The two armours have been interpreted as of a Byzantine type and would as such testify to a great influence of the Byzantines ${ }^{17}$. They could, however, have been used, likewise the afore-mentioned arrowheads, in the time of the alliance between the Langobards and the Byzantines. The excavators ascribed the two armours and the ango, as well as the destruction and fire in the building where they were found, to an attack by the Byzantine troops (or Langobard troops in their service) against a Frankish (or Alamanic) garrison ${ }^{18}$.

The archaeological finds of the $6^{\text {th }}$ and early $7^{\text {th }}$ centuries show a specific spatial distribution. The sites with

15 Odar 2006. The finds are kept in the Natural History Museum in Vienna.

16 Sagadin et al. 2016.

17 Sagadin et al. 2016, 13-15.

18 Sagadin et al. 2016, 24. 


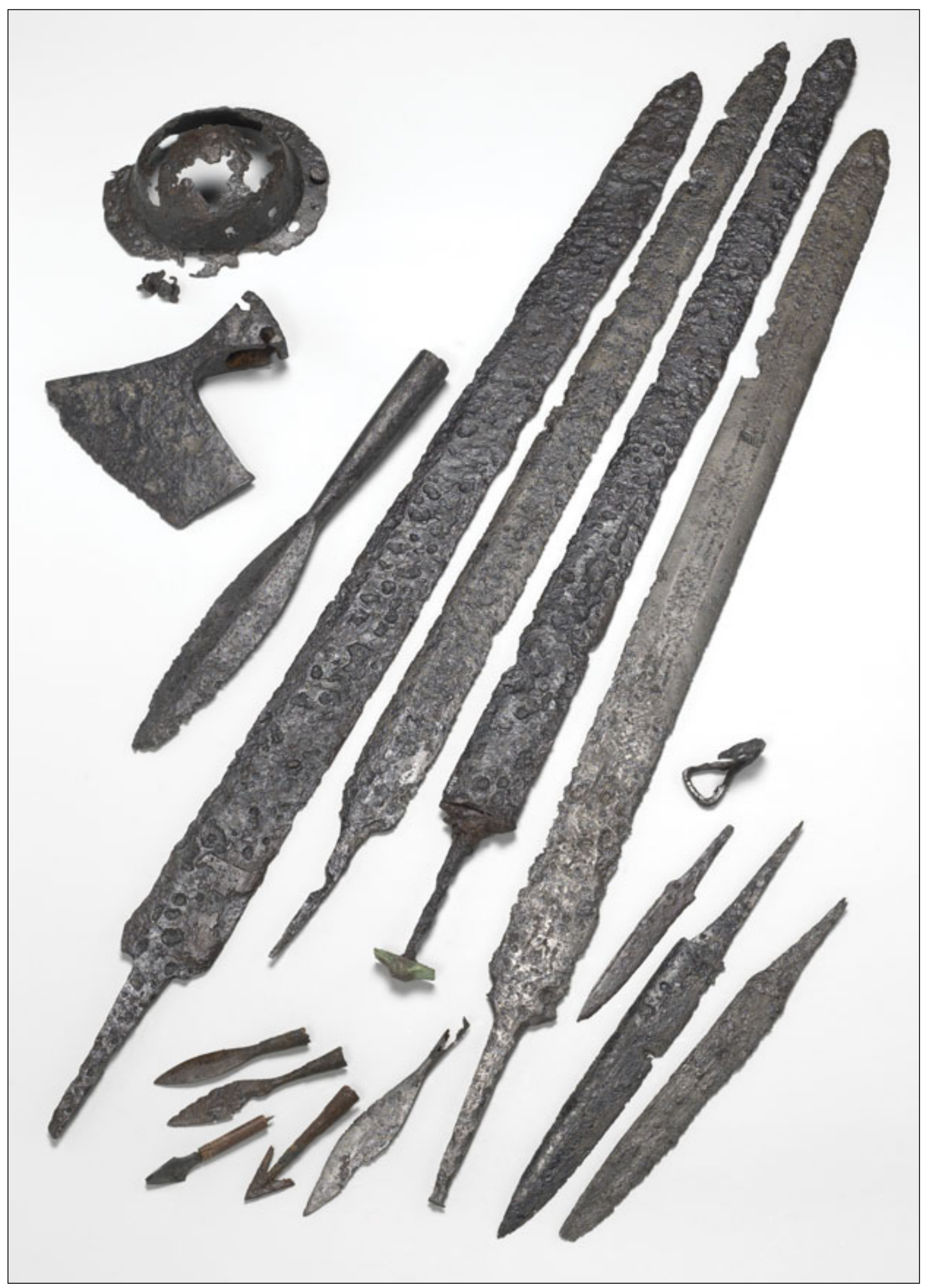

Fig. 7. Weapons from the cemetery at Lajh in Kranj, $6^{\text {th }}$ century, kept in the National Museum of Slovenia. Photo Tomaž Lauko. 
Fig. 8. Lamellar armour from the settlement of Carnium, $2^{\text {nd }}$ half of the $6^{\text {th }}$ century, kept in the Museum of Gorenjska in Kranj. Photo Tomaž Lauko.

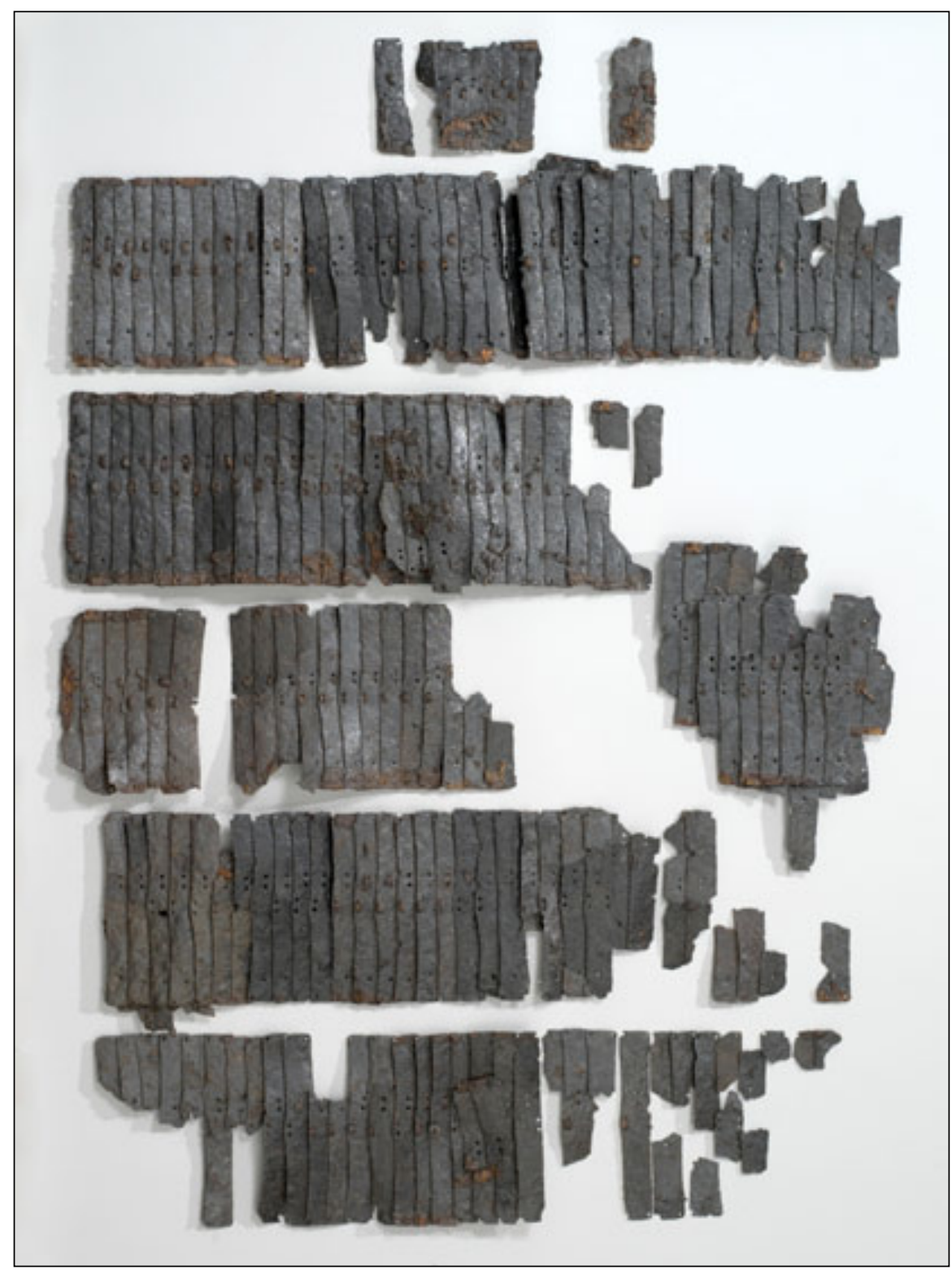

Germanic finds (Ostrogothic and Langobard cemeteries as well as finds attributed to the Franks or Alamans and to Gepids; mostly jewellery and weapons) have predominantly been excavated in the northern half of present-day Slovenia, while the Byzantine finds (coins) have mostly come to light in the southern half. Under Justinian, the Byzantines temporarily restored the power of the Roman Empire and prevented the Franks in their eastward advances ${ }^{19}$.

In addition there were the Slavs coming from the east and north, and reaching the northern Adriatic and the eastern Alps at the end of the $6^{\text {th }}$ century. They gradually settled the area bordering the Langobards and Bavarians in the west and the Avars in the east. The remains of the earliest Slavic settlements in Slovenia excavated in the north-eastern region of Prekmurje date to the late $6^{\text {th }}$ and early $7^{\text {th }}$ centuries. In the late $7^{\text {th }}$ and $8^{\text {th }}$ centuries, the Slavs settled the valleys of the Drava and Sava Rivers,

19 Dolinar et al. 2011, 39. the Ljubljana Basin and the Bled area. At Bled, they lived below the abandoned Roman hilltop settlement and buried their dead next to the graves of the Romans. To the west and especially in the coastal region of Byzantine Istria with the old towns of Capris (today Koper) and Piranon (today Piran), the Roman population continued to live in the $7^{\text {th }}$ and $8^{\text {th }}$ centuries ${ }^{20}$.

The Franks who exerted influence over areas north and west of present-day Slovenia also took control of the territory inhabited by the Carniolans. Their domination was confirmed following their victory over the Langobard Kingdom in 774-776, after which they turned towards the Avar state. Artefacts of Frankish and Avar origin from the second half of the $8^{\text {th }}$ century, such as spurs, strap ends and buckles, have been found at numerous sites in Slovenia (Figs. 9 and 10) ${ }^{21}$.

20 Knific and Nabergoj 2016, 61-69.

${ }_{21}$ Karo et al. 2011; Karo 2012b; Knific and Nabergoj 2016, 72, Fig. 84, and 75, Fig. 88. 


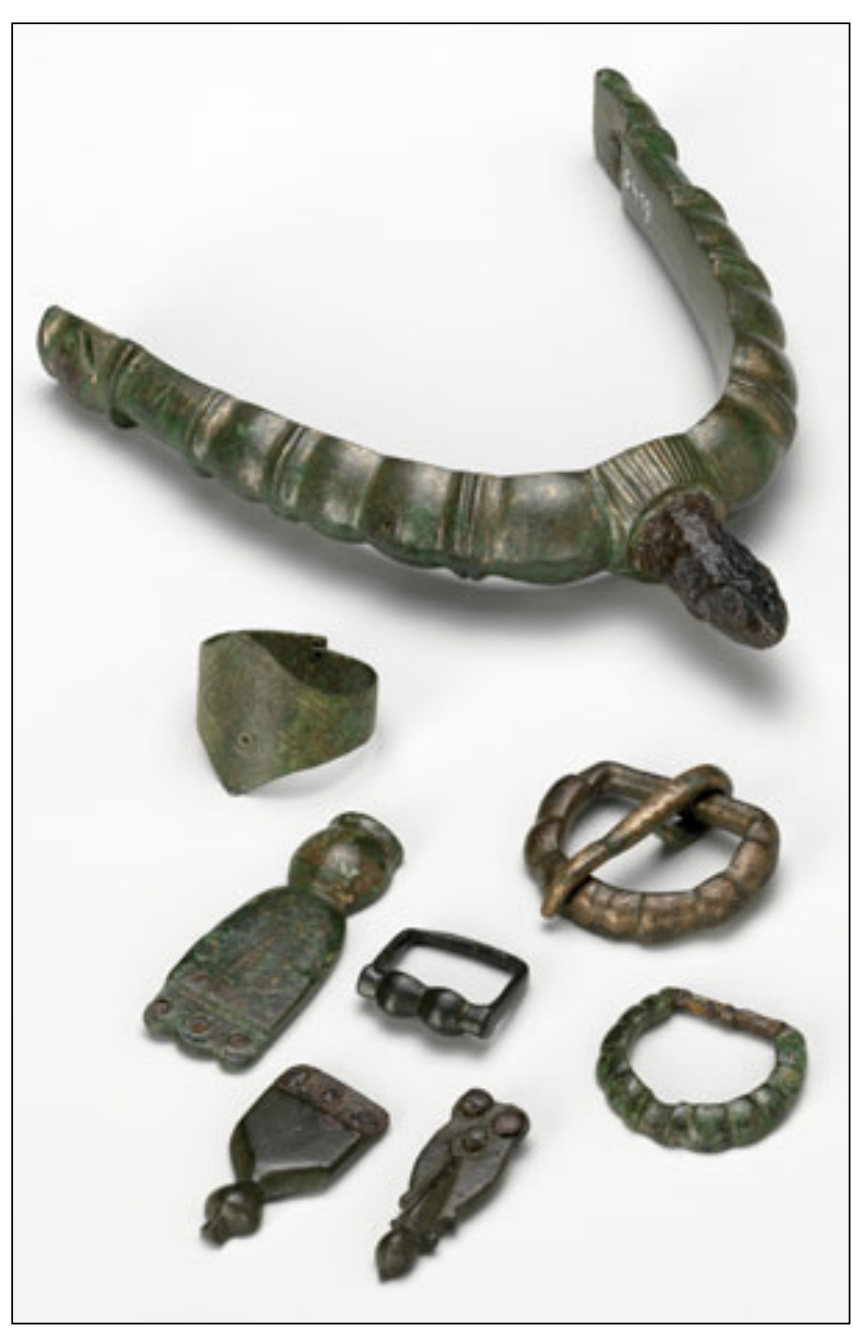

Fig. 9. Artefacts of Frankish origin, different sites, last third of the $8^{\text {th }}$-early $9^{\text {th }}$ century, kept in the National Museum of Slovenia. Photo Tomaž Lauko.

From the mid- $8^{\text {th }}$ century, the princes and elites of the Carantanian Slavs north of the Karavanke (Karawanken) Mountains (present-day Austria) and Carniolans south of them (present-day Slovenia) were forced to recognise the Frankish rule and adopt Christianity. In 788, the Franks annexed Istria and Carantania, until 803 they also subjected Carniola. In 820, the Carniolans joined the rebellion of Liudewitus Duke of Lower Pannonia (Ljudevit Posavski) against the Franks, which was unsuccessful and led to their irrevocable loss of independence. A hoard from Sebenje near Bled containing agricultural and craft tools, a pair of stirrups, horse tack and two spearheads from the first third of the $9^{\text {th }}$ century has been attributed to a Slav (Carniolan) farmer who might have hidden his possessions in the time of the Carniolan rebellion against the Franks in 820 (Fig. 11) ${ }^{22}$.

Far more numerous are the finds of spearheads at the bottom of the Ljubljanica River (late $8^{\text {th }}-9^{\text {th }}$ century), a very important and rich archaeological site (Fig. 12). Many of the spearheads are winged or have typical grooves on the

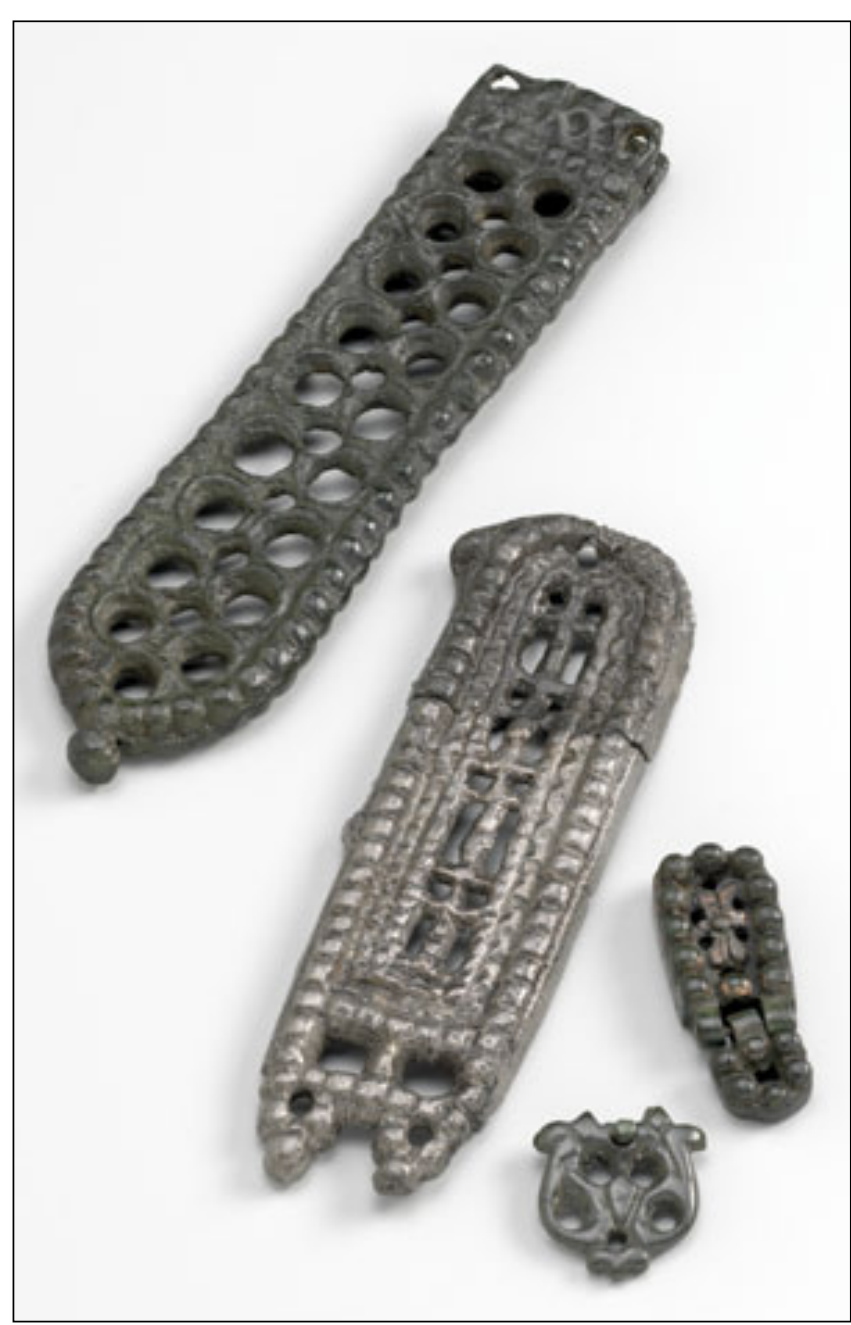

Fig. 10. Artefacts of Avar origin, different sites, $2^{\text {nd }}$ half of the $8^{\text {th }}$ century, kept in the National Museum of Slovenia. Photo Tomaž Lauko.

socket. They appeared in the Frankish lands and spread outwards, particularly to the border areas of the Carolingian state. The Franks used them in their military campaigns against the Avars (791-796), as well as against the Slavs in the Sava Valley (819-822). Various examples of such spearheads found at Rakova Jelša near Ljubljana gave rise, together with some traces of a structure nearby, to the idea of a possible Frankish wooden fortress located near the confluence of the Ižica and Ljubljanica Rivers ${ }^{23}$.

The period of the Frankish rule over the present-day Slovenian territory from the late $8^{\text {th }}$ to the early $10^{\text {th }}$ century saw the emergence of quite a few posts or fortified settlements on hilltops. Many of them were built on hills already occupied in Late Antiquity. One of the most important ones is Gradišče above Bašelj, north of Kranj, with a strategic position controlling the path towards the Bašelj Pass and across the Jezersko (Seeberg) Pass to Carinthia. Its terraced hilltop was naturally protected by steep slopes and held the remains of a settlement. It yielded numerous weapons 


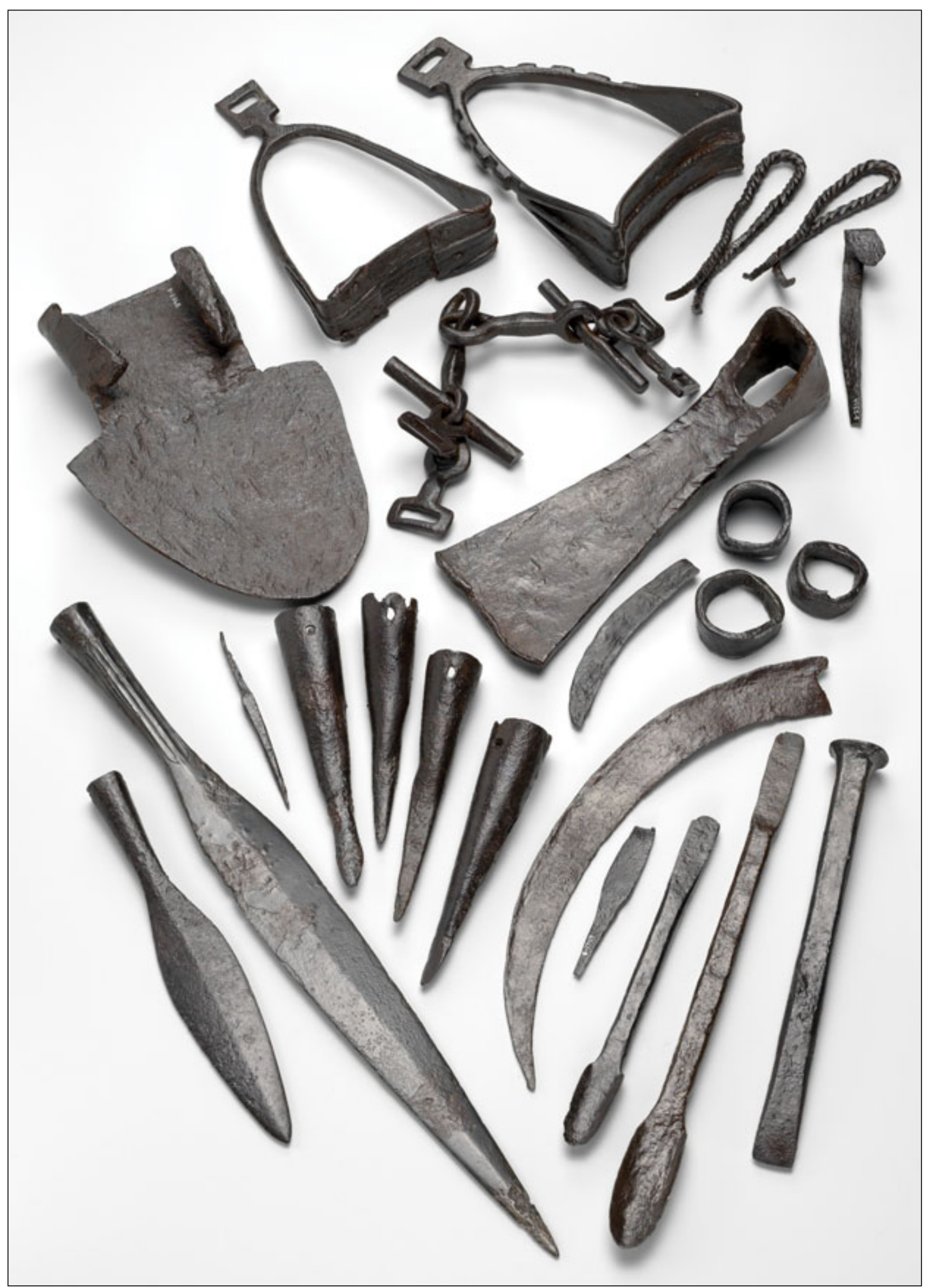

Fig. 11. Hoard from Sebenje near Bled, first third of the $9^{\text {th }}$ century, kept in the National Museum of Slovenia. Photo Tomaž Lauko. 


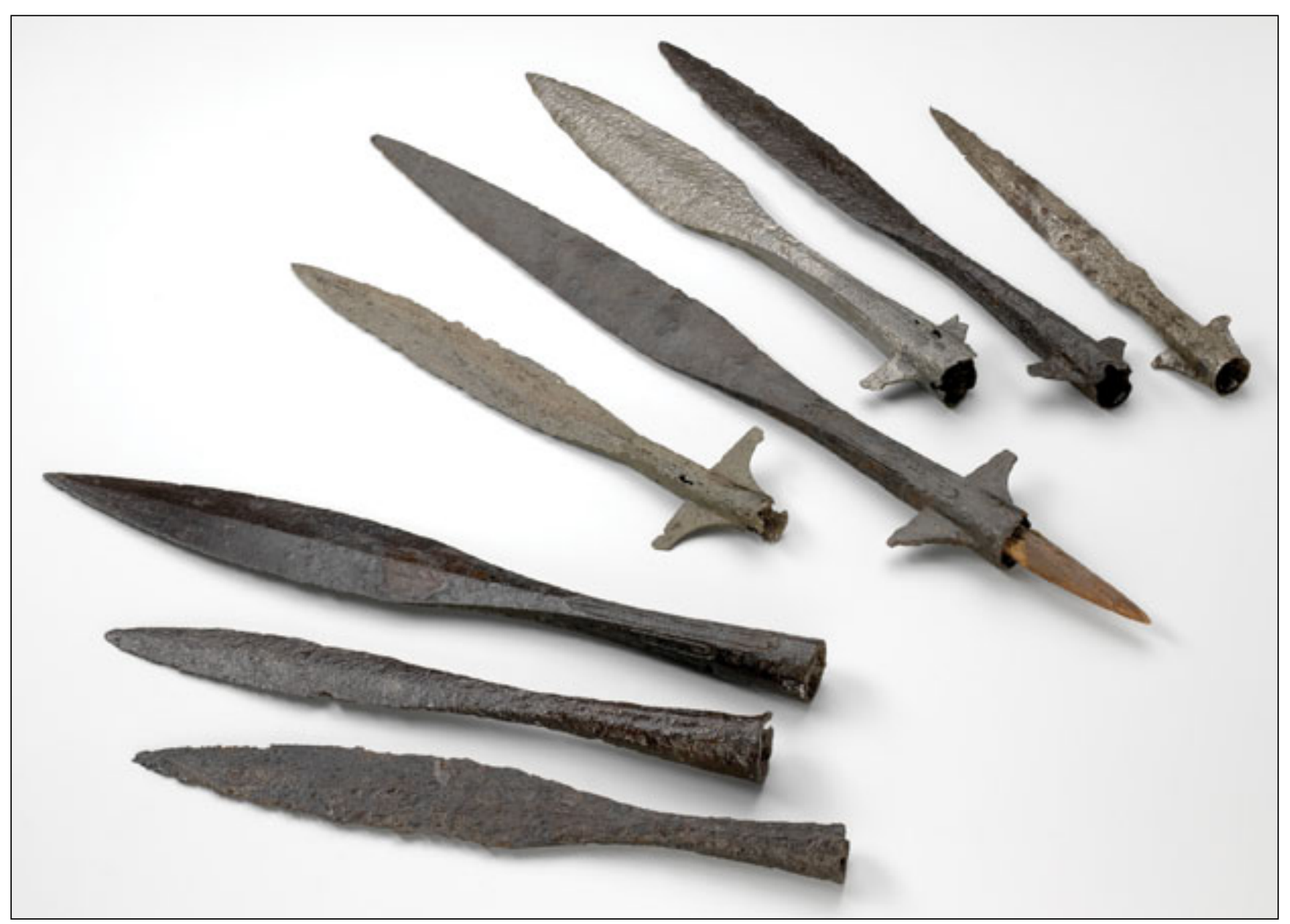

Fig. 12. Spearheads from the Ljubljanica River (late $8^{\text {th }}-9^{\text {th }}$ century), kept in the National Museum of Slovenia. Photo Tomaž Lauko.

and pieces of military equipment such as sword pommels, sword belts, arrowheads, combat knives, scabbard mounts and axes.

The high-quality iron artefacts include a special group of horse and equestrian equipment such as spurs, bridles, stirrups, strap dividers and saddle buckles (Fig. 13). Some were prestigious objects, if judging from their ornaments, with parallels from sites in Slovakia and the Czech Republic dated to the time of the Great Moravian Empire. One such item is a gilded bronze strap divider similar to a pair of dividers from Blatnica in Slovakia that were unearthed in a princely grave from the beginning of the $9^{\text {th }}$ century (Fig. 14) ${ }^{24}$.

The political and military situation in Europe at the end of the $9^{\text {th }}$ and in the first half of the $10^{\text {th }}$ century was dramatically affected by the Hungarian (Magyar) raids which began in 894 when they first crossed the Danube and devastated Pannonia (where they eventually settled in the following years). The present-day Slovenian territory was an area of passage for the Hungarian raids to the west, i.e., to Italy as well as further westwards, to the West Frankish

${ }^{24}$ Karo 2012a; Karo and Knific 2015; Knific and Nabergoj 2016, 83-89, Figs. 100-103.
Kingdom and the Iberian Peninsula. There were at least twenty-two raids, from the large-scale incursion to Italy in 899 and the defeat of the Italian army under King Berengar at the Brenta River, to the last huge Hungarian campaign to European countries in 954 when they once again crossed the Alps. In 955, the Hungarians were finally beaten by the German King Otto I and his large army in the Battle of Lechfeld near Augsburg.

From the second half of the $10^{\text {th }}$ and the $11^{\text {th }}$ century, the medieval German Kingdom, later extended to the Holy Roman Empire, began to exert control over vast parts of Europe, including most of the present-day Slovenian territory (Fig. 15). New political entities emerged after c. 1000 on the Empire's south-eastern border with Hungary and Croatia: marches of Carantania, Saunia, Carniola, Istria and Friuli. From the $11^{\text {th }}$ century onwards, these border units began to separate from the Duchy of Carinthia (established in 976 from the former Stem Principality of Carantania). In the following centuries (until roughly 1500) they gradually formed the provinces of Carinthia, Styria, Carniola and Gorizia. They remained part of the Holy Roman Empire to its dissolution in 1806. Then, for a century they were part of the Austrian Empire, with the exception of the Prekmurje region (north-eastern Slovenia) that for centuries and until 1918 belonged to the Kingdom of Hungary. 


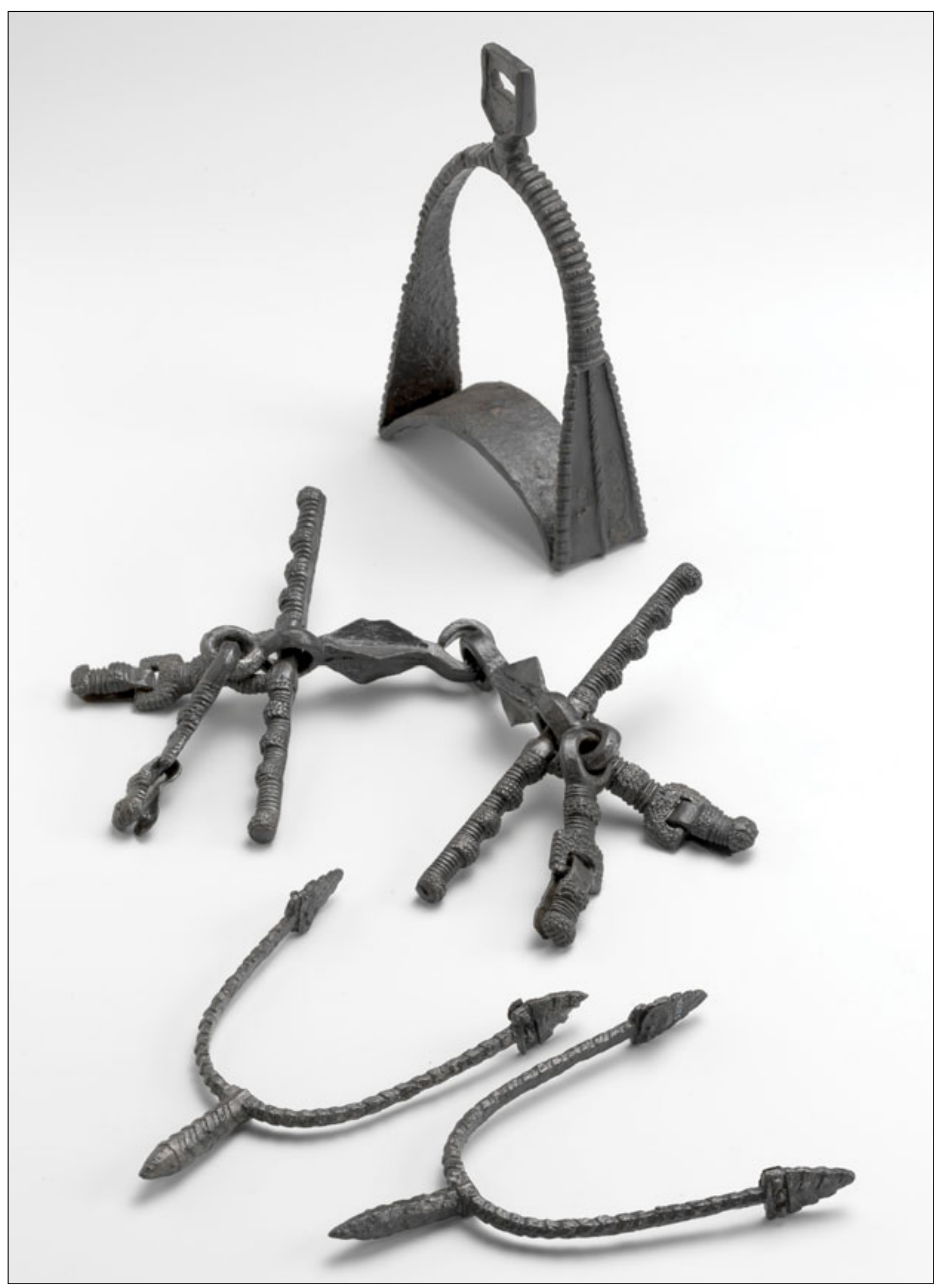

Fig. 13. Stirrup, bridle and a pair of spurs from the $9^{\text {th }}$ century, buried as a hoard at Gradišče above Bašelj; kept in the National Museum of Slovenia. Photo Tomaž Lauko. 


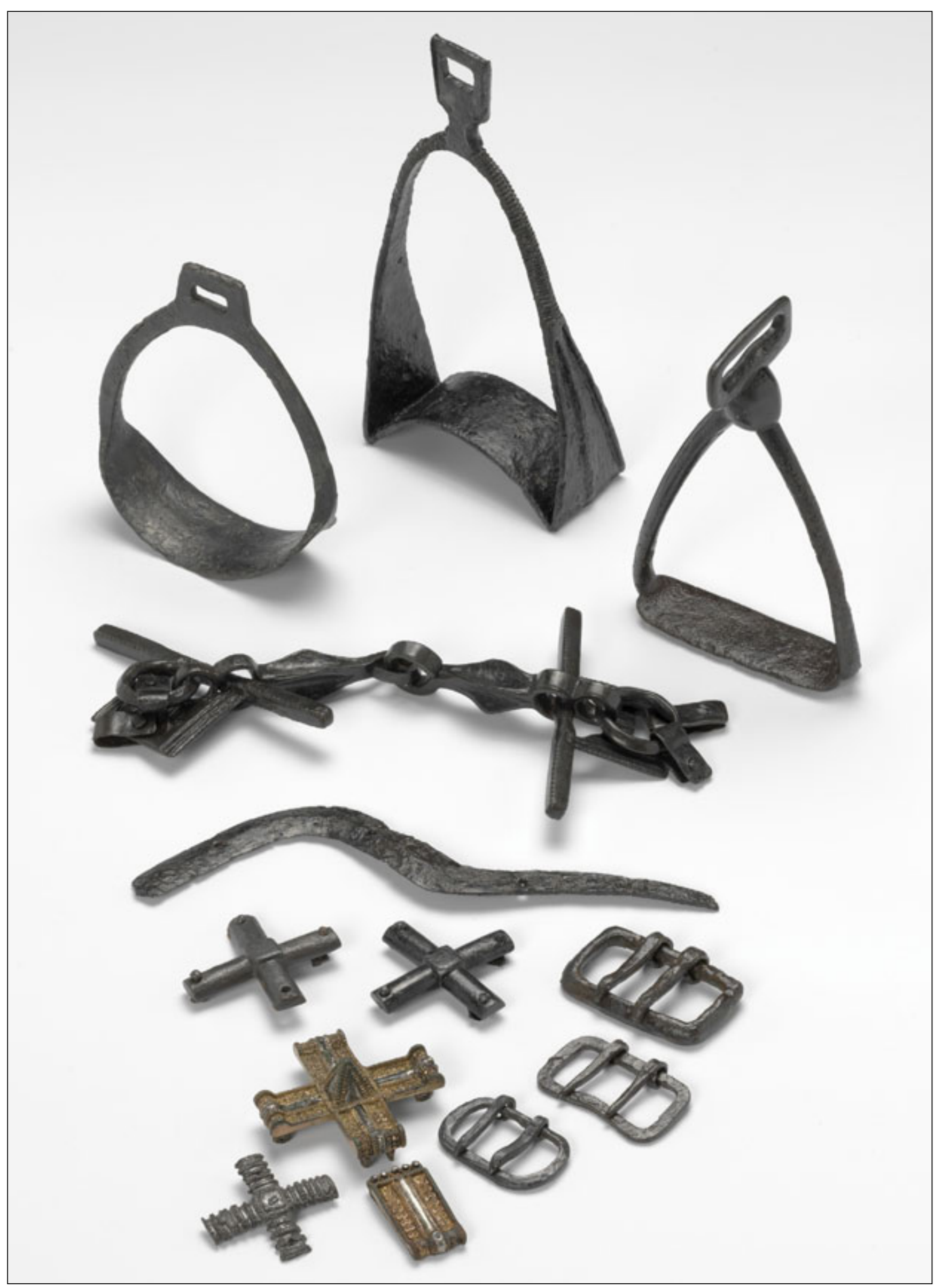

Fig. 14. Horse equipment from various hilltop settlements of the $9^{\text {th }}$ and early $10^{\text {th }}$ centuries in Slovenia, kept in the National Museum of Slovenia. Photo Tomaž Lauko. 
Fig. 15. Germany (later Holy Roman Empire) around 1000.

Map Vida Bitenc - after Knific and Nabergoj 2016, Fig. 127.

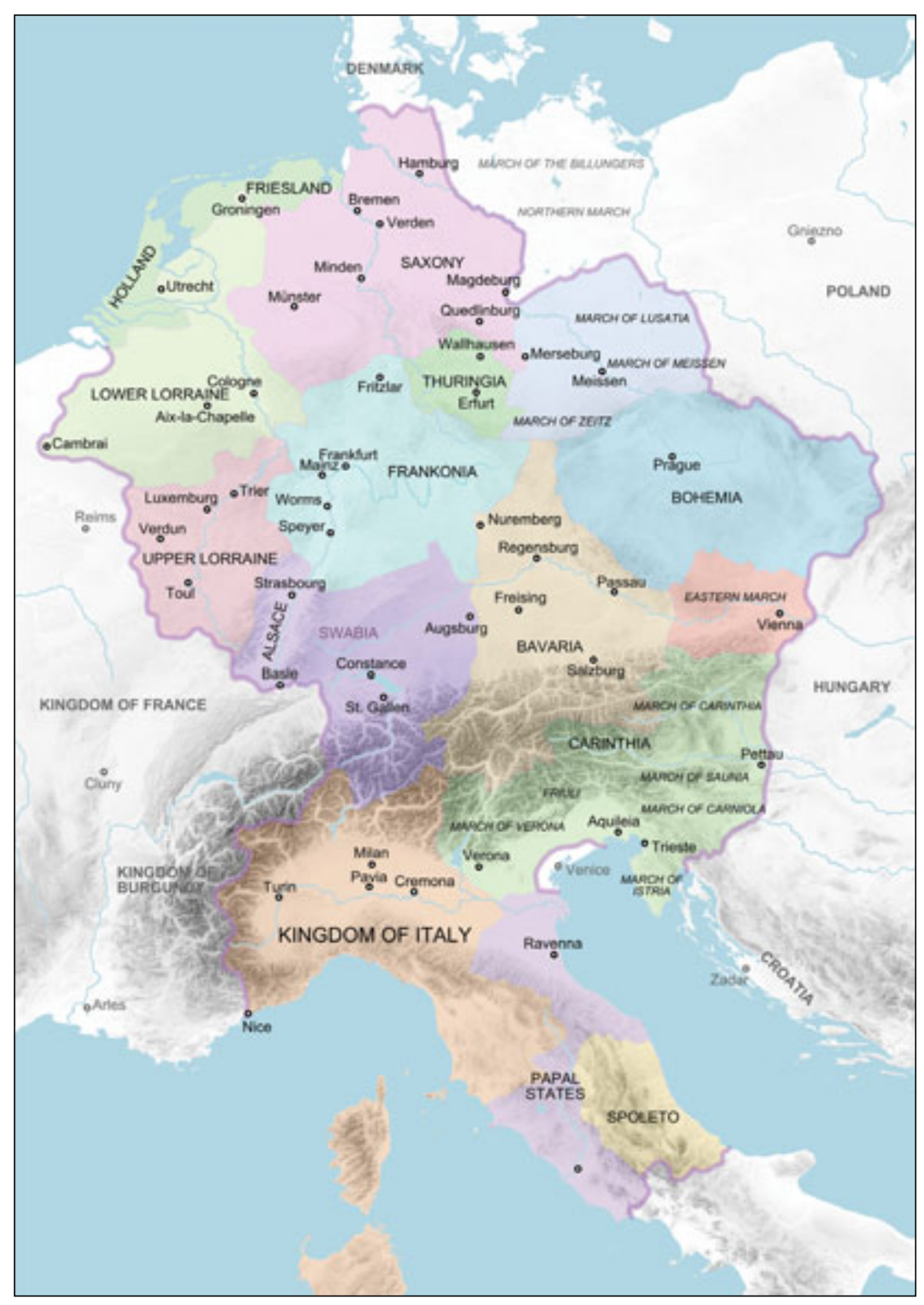

The coastal towns of Koper, Izola and Piran together with their Slovenian hinterland were part of the Venetian Republic from the $13^{\text {th }}$ to the late $18^{\text {th }}$ century.

The political and military development of the presentday Slovenian territory in the High and Late Middle Ages (roughly from the $11^{\text {th }}$ to the $15^{\text {th }}$ century) is a complex affair and even a brief outline of it would go beyond the scope of this short article ${ }^{25}$. Its most relevant feature, however, is the continuing strategic importance and the transitory character of this territory at the crossroads between Italy and Hungary, but also between the south-eastern Alpine regions and the Balkan Peninsula. The main late-medieval roads that largely followed the former Roman road

25 There have not been many studies on this issue. On medieval warfare in Slovenian lands in the Late Middle Ages cf. Lazar 2012. On late medieval artillery in Slovenian lands cf. Lazar 2015. system were essentially intended for trade and transport, but were equally important for military purposes and journeys of individuals. The first main route of transit led from Hungary via Ptuj, Celje and Ljubljana to Venice and northern Italy. The second main route went from Vienna via Graz, Maribor and Ljubljana to Trieste (Fig. 16) ${ }^{26}$.

The geographic position and the political circumstances were such as to offer soldiers from this region a possibility to make a living as mercenaries abroad, especially in northern Italy and in Hungary, and to return home with valuable experiences in fighting techniques and in military organisation. It also meant there was access to the most up-to-date knowledge in military technology. This was also due to the proximity of important armouries in Lombardy, primarily in Milan and Brescia where, for example,

26 Kosi 1998. 


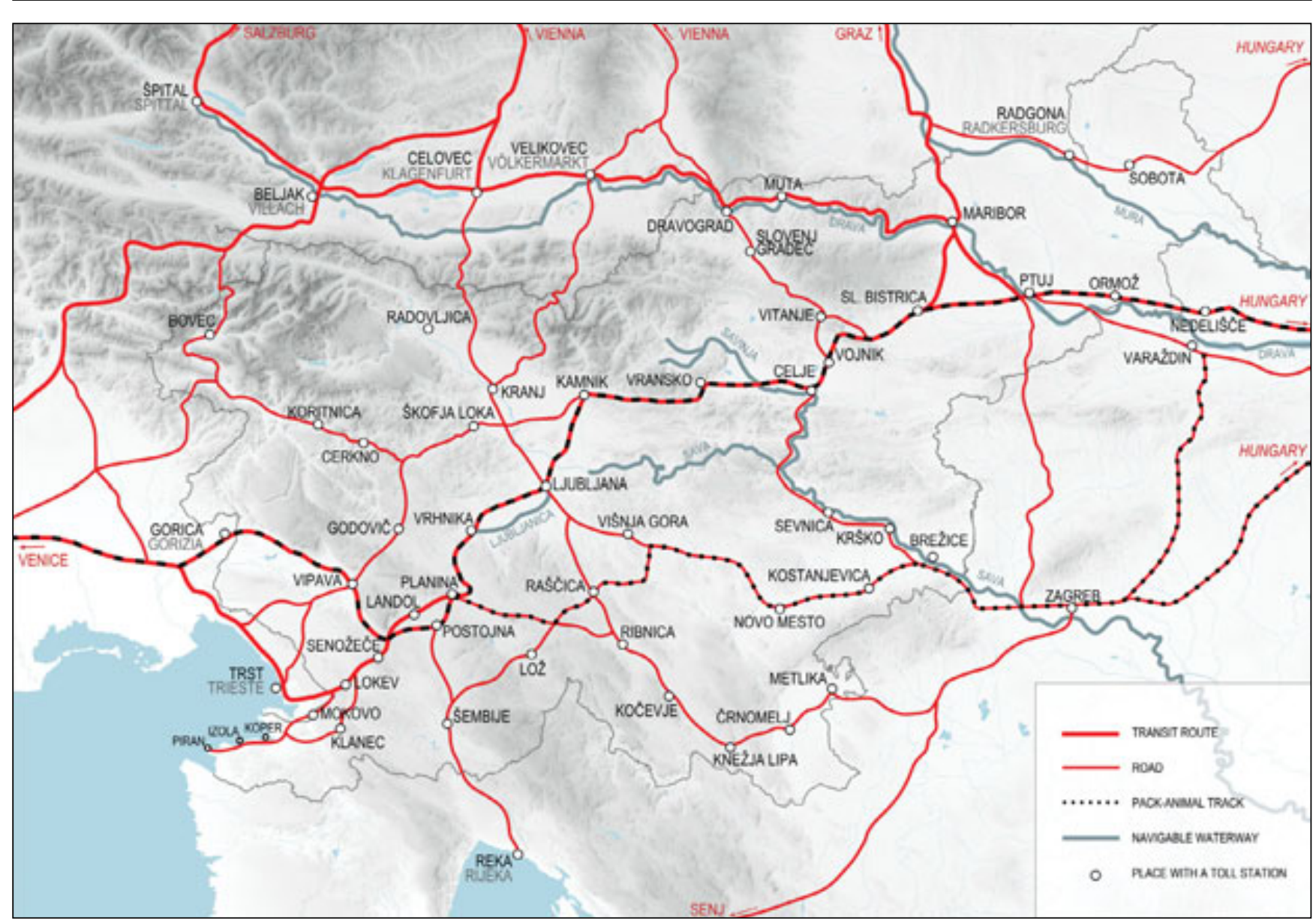

Fig. 16. Main routes in the territory of present-day Slovenia in the Late Middle Ages. Map Vida Bitenc - after Knific and Nabergoj 2016, Fig. 197.

the full harness of plate armour was being produced by 1400. Equally relevant were the south German production centres of plate armour and mail, such as Augsburg, Nuremberg, Innsbruck and Landshut, but also Passau with its renowned production of edged weapons. It is noteworthy that the earliest written mention of firearms in Europe dates to 1331 when cannons were used in the siege of Cividale in Friuli, on the western border of the Slovenian ethnic territory, and that in the mid-14 ${ }^{\text {th }}$ century (at least in 1350) the Counts of Görz already used cannons as a regular part of their weaponry ${ }^{27}$.

In the High and Late Middle Ages, noblemen from the present-day Slovenian territory took part in various military expeditions, often as an obligation to their ruler, particularly to Italy. They also went to various other parts of Europe, from German and Baltic lands to the Balkan and Iberian Peninsulas, as well as participated in crusades to the Holy Land. The most notable were the families of Spanheim, Babenberg, Andechs-Meran and the lords of Görz (Gorizia), together with their ministeriales such as those from Ptuj (Pettau) and Scharffenberg. Among the most prominent families assisting the Emperor and

27 Cf. Lazar 2012, 10, 130-133; Lazar 2015, 29. the provincial dukes were the Counts of Ortenburg and the Counts of Cilli ${ }^{28}$.

Several countries, dynasties and realms included obtaining the access to the Adriatic Sea into their policies. We should mention the plans of the Czech King Přemysl Otakar II, who around 1270 managed for some years to connect and unify territories from the Czech lands and Austria to the Adriatic Sea under his rule. Otakar succeeded in becoming Duke of Austria, Styria and Carinthia, as well as Margrave of Carniola (1269-1276) and Captain General of Friuli (1272) but was thwarted in his ambition to be crowned emperor by his defeat against the Habsburgs. It was the latter who were the most successful in this respect. After the victory of Rudolf I over Otakar in the Battle of Dürnkrut in 1278, they had the opportunity to gain vast territories in the eastern Alps, securing Austria, Styria and Carniola for Rudolf's sons and controlling Carinthia with the help of their allies, the Counts of GörzTyrol. In the $14^{\text {th }}$ century, the Habsburgs succeeded in obtaining the feudal domains in the Karst region (Postojna

28 Cf. a miscellany of articles and a catalogue of the exhibition on chivalry in Slovenian lands in the National Museum of Slovenia: Lazar et al. 2011; Lazar et al. 2013. For the mercenary activities of the Counts of Cilli cf. Lazar 2012, 125-129. 


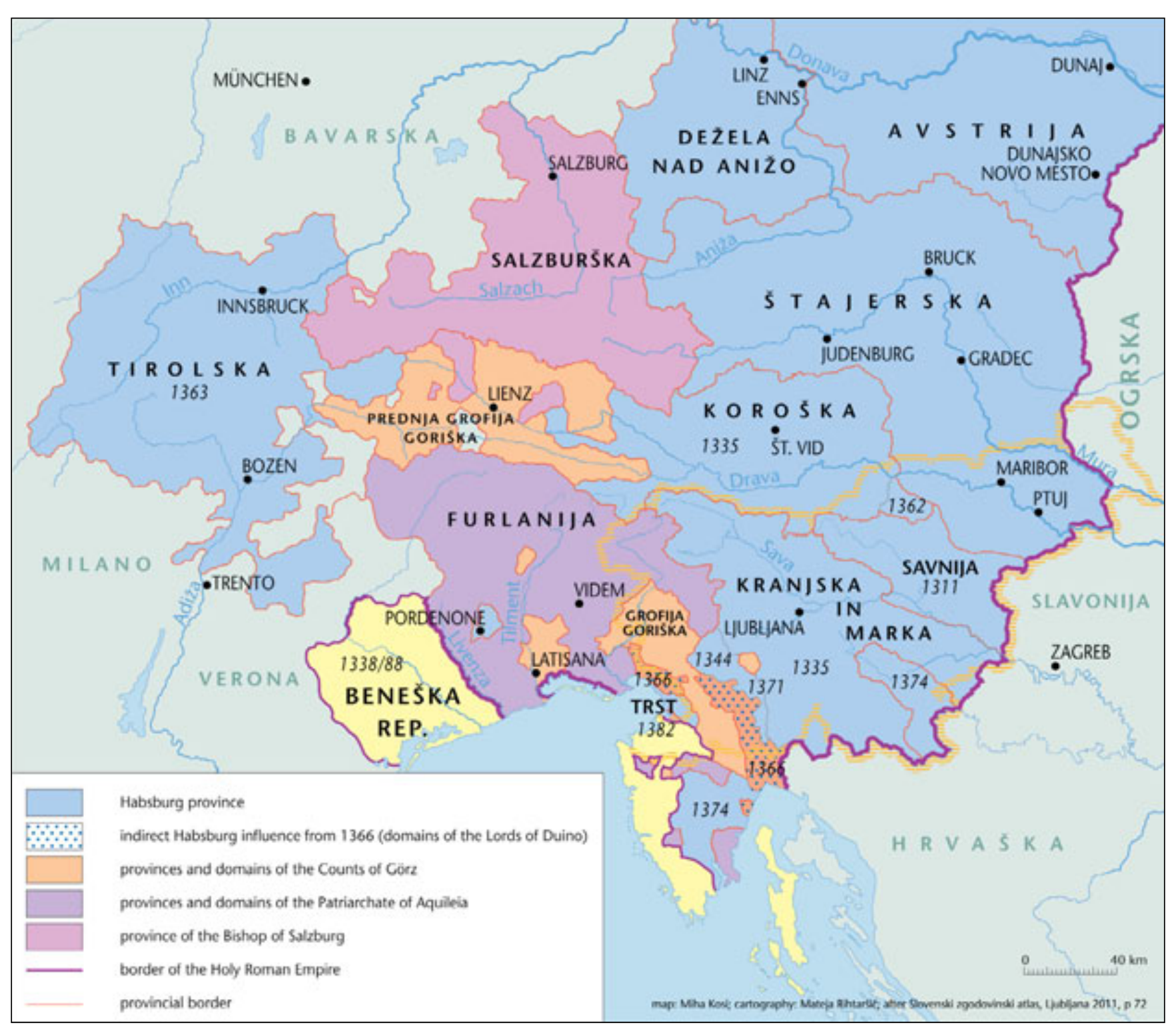

Fig. 17. Expansion of the Habsburgs to the Adriatic up to the end of the $14^{\text {th }}$ century. Map Mateja Rihtaršič - after Dolinar et al. $2011,72$.

and Vipava) as a bridge to the Adriatic. Most crucially, they subordinated Trieste in 1382, which was the only port in the northern Adriatic area to escape the expansion of the Venetian Republic (Fig. 17).

In the first half of the $14^{\text {th }}$ century, the provinces in present-day Slovenia contributed a large number of troops and mercenaries to fight in battles and wars in northern Italy. The most important were the campaigns of Count Henry II of Görz and Duke Henry of Carinthia against Cangrande della Scala from Verona, which is reasonably well documented and can reveal much about the military organisation of this territory ${ }^{29}$. Even more significant were the military activities of the Counts of Cilli (Celje) who, by gaining in importance as loyal vassals to the Habsburgs from the mid-14 ${ }^{\text {th }}$ century and especially in the first half of the $15^{\text {th }}$ century, became the most powerful feudal lords originating from the territory of Slovenia ${ }^{30}$. After Count Hermann II had saved the life of the Hungarian King Sigismund of Luxembourg in the Battle at Nicopolis in 1396 and the King (who became Emperor in 1433) had married Hermann's daughter Barbara in 1405, the Counts of Cilli also became one of the most influential dynasties in central Europe. Under Ulrich II, they rivalled King Frederick V of Habsburg as well as the Hunyadis from Hungary, planning to rule Hungary in the name of the underage King Ladislaus the Posthumous. However, the Habsburgs defeated them in the 1437-1443 wars and their dynasty came to an abrupt end in 1453 when Ladislaus Hunyadi and his soldiers killed Ulrich II in Belgrade. The war for the legacy of the Cilli which took place in various parts of present-day Slovenia involved many parties, from the Emperor Frederick III, King Ladislaus, the Counts

29 Lazar 2012, 65-106.

30 Cf. Mlinar 2005. 


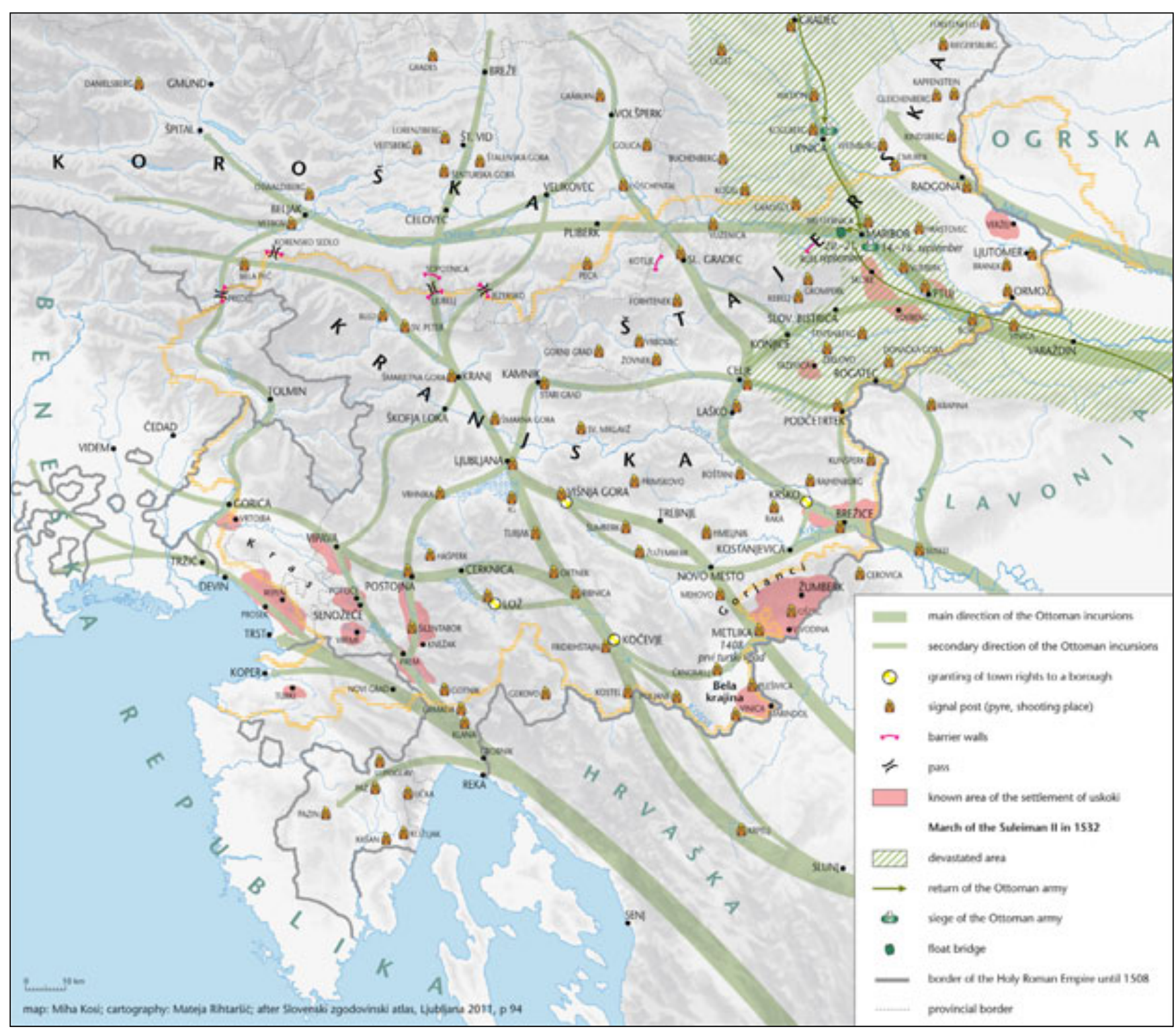

Fig. 18. Ottoman incursions to the Slovenian lands in the $15^{\text {th }}$ and $16^{\text {th }}$ centuries. Map Mateja Rihtaršič - after Dolinar et al. $2011,94$.

of Görz, the Frankopans to Ulrich's widow Katarina Branković (with her general/commander Jan Vitovec who then sided with the Emperor) and Countess Margaret, daughter of Hermann III of Cilli. In the Treaty of Pusarnitz in 1460, the Emperor achieved his goals against the Counts of Görz, and even before that he had successfully settled the matter with Katarina Branković. Thus, the Habsburgs finally came into the possession of the legacy of the Cilli ${ }^{31}$.

There were only a few very large and long-running campaigns taking place in the territory of Slovenia in the High and Late Middle Ages; most warfare was smallscale. Among the documented campaigns led by rulers ${ }^{32}$, we should mention, as an example, the campaign of King

31 Lazar 2009, 311-323.

32 Cf. two maps made by Miha Kosi with relevant data on the voyages and campaigns of rulers across the territory of Slovenia from the $11^{\text {th }}$ to the $15^{\text {th }}$ centuries, in Dolinar et al. 2011, 73 .
Sigismund of Luxembourg from Hungary via Ljubljana to Friuli in his war with Venice in 1412. In his chronicle from the beginning of the $15^{\text {th }}$ century Eberhard Windecke mentions that the king's army was not allowed to enter Ljubljana (as it was held by the Habsburgs). Sigismund had some 40000 men under his command who broke into the suburbs and then proceeded along the Ljubljanica River to the Karst region and further to Friuli ${ }^{33}$.

Much more severe were the incursions of the Hungarian King Matthias Corvinus during his wars with Emperor Frederick III which lasted, with interruptions, from 1477 until Matthias' death in 1490 (mainly 1482-1487). They brought military occupation and devastation, especially to the Inner Austrian Lands, and the Ottoman invasions in 1469-1483 only worsened the situation. In the territory of present-day Slovenia the Hungarians mainly occupied

33 Altmann 1893, 10-11. 


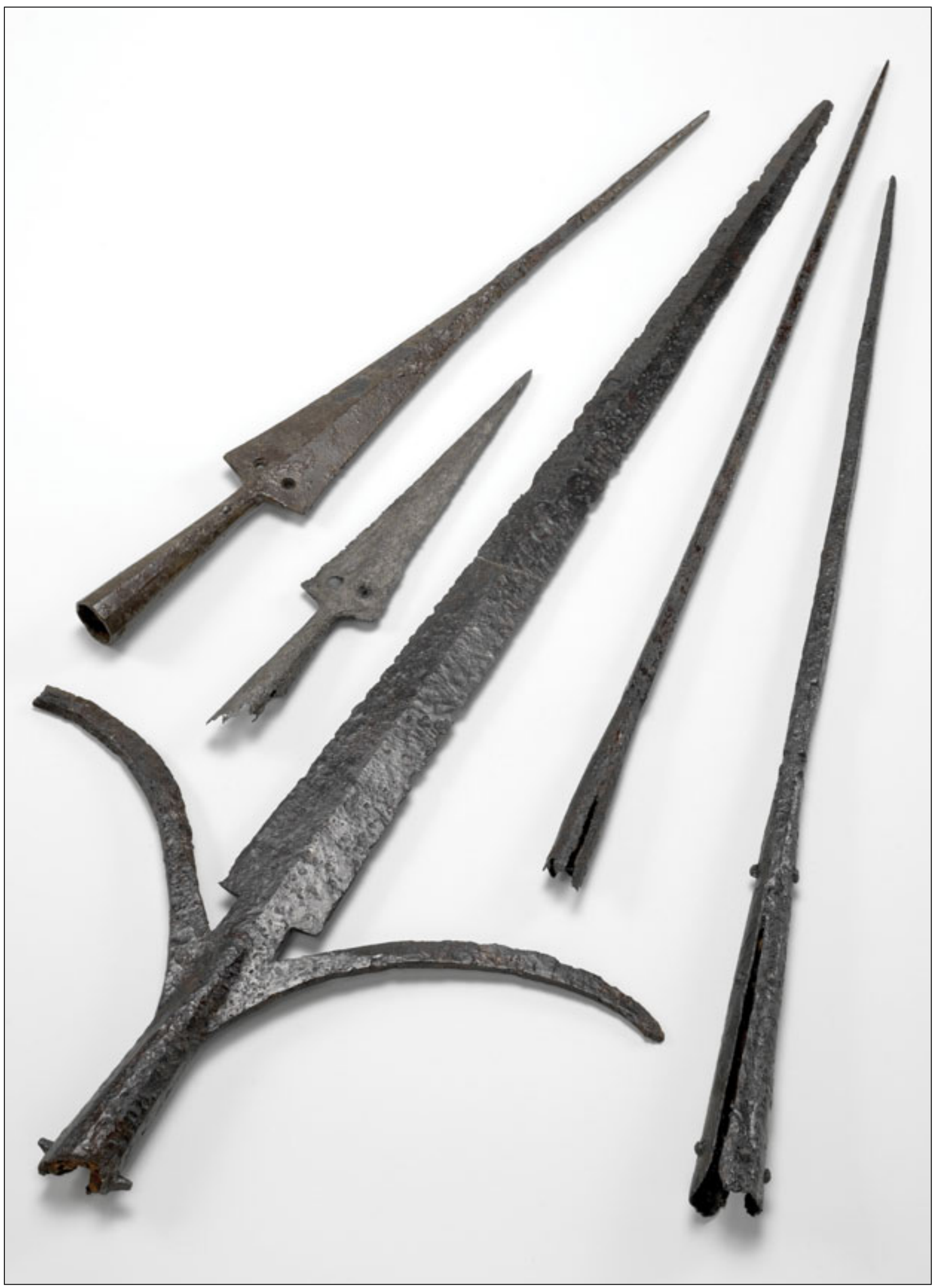

Fig. 19. Typical weapons of mercenary heavy infantry: spearheads, awl pikes and a corseque (Friulian polearm) from the Ljubljanica River, $15^{\text {th }}$ and $16^{\text {th }}$ centuries, kept in the National Museum of Slovenia. Photo Tomaž Lauko. 
towns and estates in Styria and Carinthia. They even attacked Trieste and nearby Duino (Devin) in $1485^{34}$.

It was the Ottoman invasions from 1408 onwards that changed the nature of military activities in this area and significantly affected the life of the population in the $15^{\text {th }}$ and $16^{\text {th }}$ centuries (Fig. 18). After the fall of Bosnia in 1463, the Ottoman State was just over $100 \mathrm{~km}$ from Carniola. The heaviest attacks with devastating consequences followed in 1469-1483, especially in Carniola, Carinthia and Styria, often more than once a year, but sometimes also in Gorizia, Karst, Friuli and Istria. After the end of the truce between Matthias Corvinus and the Ottomans (1483-1490), further incursions, even if not as severe, followed in 1491-1499, 1511 and 1516. New Ottoman invasions occurred in 1522-1532 when Suleyman the Magnificent destroyed the Hungarian army in the Battle of Mohacs (in 1526), took Buda and besieged Vienna for the first time (in 1529). Following the second siege of Vienna in 1532, the Ottoman incursions to the Inner Austrian lands became rare, after 1600 only threatening the territory of present-day Slovenia in Prekmurje. The defence against the Ottomans in the $15^{\text {th }}$ and $16^{\text {th }}$ centuries was limited to fortifying towns and castles (which the attackers sought to avoid), as well as organising a signalling system. The countryside suffered most - up to 200000 individuals from Carniola, Carinthia and Styria were taken captive until 1508. The rural population sought refuge against the Ottomans in fortified settlements - rural fortifications called tabor, mostly built around a church. There were around 350 tabors erected in the territory of present-day Slovenia ${ }^{35}$. The Ottomans were only decisively defeated at the epic Battle of Sisak in 1593, which took place near the Kolpa (Kupa) River in Croatia ${ }^{36}$.

In 1500, Venetian authorities hired a military engineer Leonardo da Vinci to make a defence plan against the Ottomans. Leonardo visited the area at the confluence of the Soča (Isonzo) and Vipava (Vipacco, Wippach) Rivers and drew a plan to dam the rivers and thus cause flooding of the area to prevent the attacks of the Ottoman cavalry. Flooding should not have affected the bridge in Gorizia. It was planned to be defended by 'bombing', apparently using artillery from the nearby settlement of Gradisca $^{37}$. The last major military conflict at the end of the Middle Ages or the beginning of the Early Modern Era in the area under discussion mostly raged in central northern Italy: it was the conflict between the Habsburgs and Venetians (1508-1516) which later escalated into the War of the League of Cambrai ${ }^{38}$. It was part of the Great Italian Wars

34 Cf. Dolinar et al. 2011, 97 (maps by Miha Kosi).

35 Cf. Dolinar et al. 2011, 94-95 (maps by Miha Kosi).

36 Cf. Žargi 1993.

37 The plan dated to 1500 is preserved in the famous Codice Atlantico kept today in the Biblioteca Ambrosiana in Milan. Cf. Sitar 1989.

38 Cf. Dolinar et al. 2011, 99 (map by Miha Kosi).
(1494-1559) where various countries and city-states from all over Europe were engaged: besides Austria and Venice, also France, Spain, the Swiss Confederation, the Holy See, Milan, Florence etc. The eastern zone of conflict was in Friuli, Gorizia and Istria, which significantly affected the present-day Slovenian territory. Its main consequence after the truce in 1516 and the peace treaty in 1521 (1523) was that the Upper Soča (Isonzo) Valley (together with the mercury mine in Idrija), Gradisca with Aquileia and some domains in the Karst region were given to the Austrians, while Venice got some domains in Istria. This treaty set the western borders of the Habsburg Hereditary Lands for the next three centuries.

What material evidence do we have in the Slovenian museum collections to support the knowledge on historic events from the $11^{\text {th }}$ to the $15^{\text {th }}$ or $16^{\text {th }}$ century as gained from the documentary sources? There is a discrepancy in terms of quantity and variety of museum items as remnants of military events and the 'military culture' in the High and Late Middle Ages, also in comparison with the finds from the Early Middle Ages or Late Antiquity. The latter mostly came to light during archaeological excavations, are often quite precisely dated and belong to specific contexts, especially graves and cemeteries, but also settlements, fortresses and even hoards. In contrast to these, the objects dated to High and Late Middle Ages are often stray finds from castles and urban settlements (apart of some well preserved objects from old private collections usually without reliable documentation as to their provenance). They are not numerous and none originate from a specific site such as a battlefield or a military camp. This situation is mainly the consequence of the history of collecting antiquities, especially in the first half of the $20^{\text {th }}$ century when many collections were sold at auctions or were destroyed in World War II, but also of the development and role of archaeology in Slovenia. For a long time, archaeologists did not adequately and systematically research periods following the Early Middle Ages or issues pertaining to castles and other fortifications. It is only from the 1980s onwards that we have witnessed a significant shift in the methodological and theoretical approaches to the archaeology of medieval and post-medieval periods $\mathrm{s}^{39}$.

There are certain issues or fields that are not documented with material remnants, a good example being medieval arms and armour from Slovenian coastal towns. These were under Venetian rule for centuries and their citizens were serving in Venetian troops or were at least active in guarding or maintaining town fortifications, not to mention carrying weapons as part of their attire (Fig. 20). Archival sources mention the following arms and armour of the citizens of Piran in the $13^{\text {th }}$ and $14^{\text {th }}$ centuries: sword (spada, ensis), armour (coraçia, lamera), body armour (pançeria), breastplate (coretus), gorget (golarum), arm defences

39 Cf. Predovnik and Nabergoj 2010. 


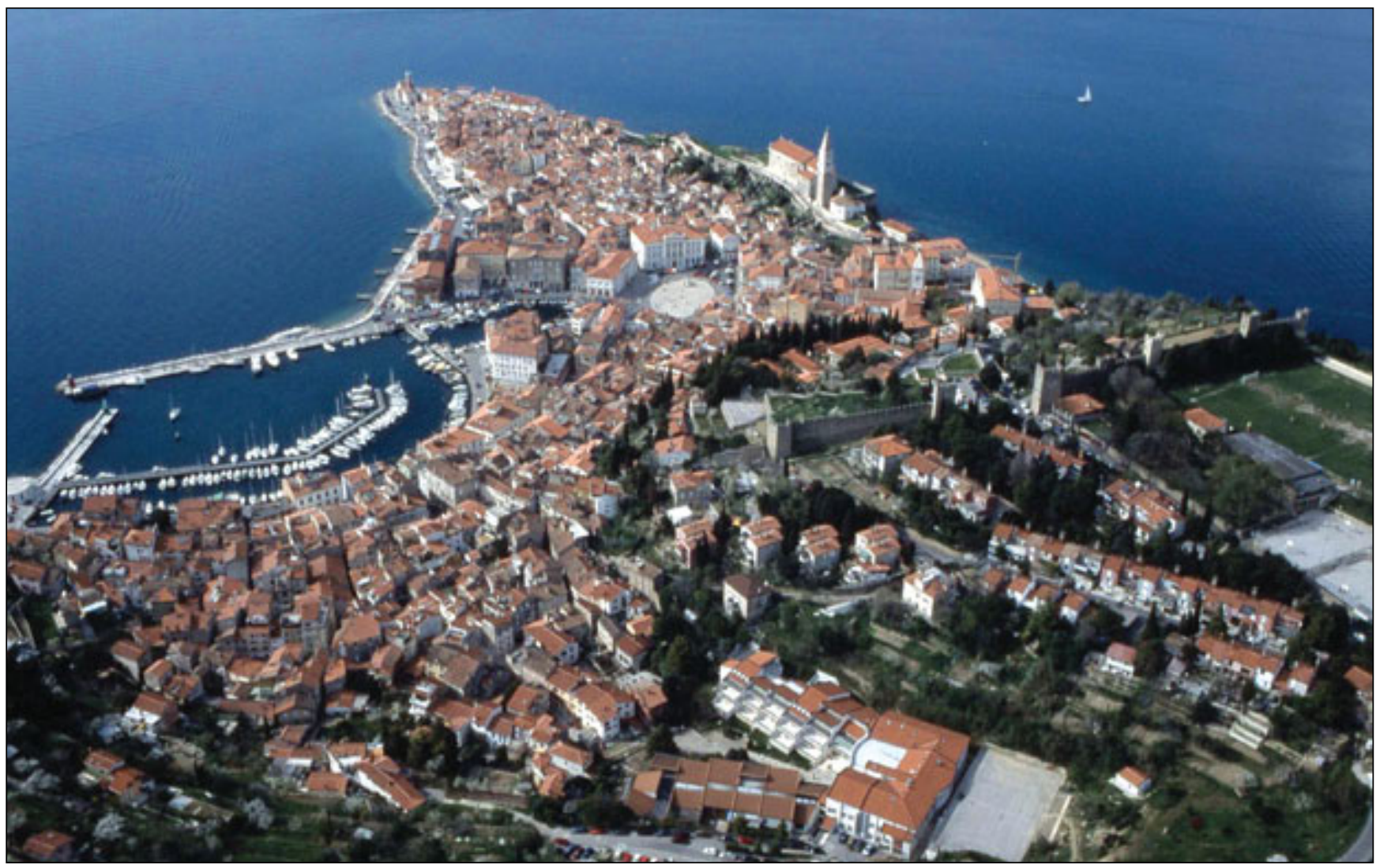

Fig. 20. The city of Piran, Slovenia, with preserved medieval walls. Photo Jože Hanc.

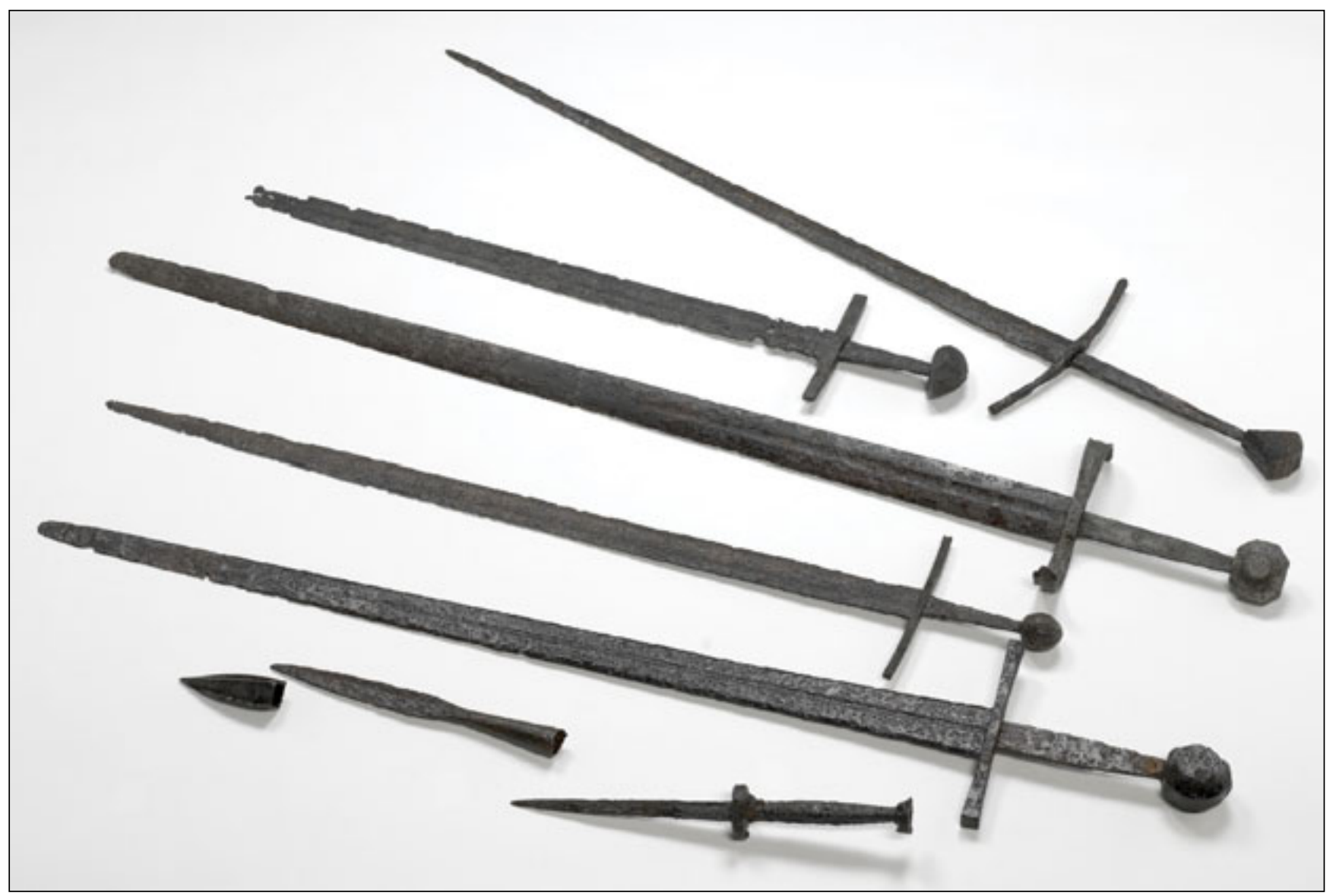

Fig. 21. Swords, spearheads and a dagger from the Ljubljanica River, $11^{\text {th }}-15^{\text {th }}$ century, kept in the National Museum of Slovenia. Photo Tomaž Lauko. 
(braçale), leg defences (gambera), helmet (capelus, capilina), shield (clipidus, talavaçus), round shield (targia, rotella), lance (lançonus), bill (ronchonus), spiked club (spontonus), knife (lançeta, penatum), crossbow (balista) with a spanning aid (crochus). None of such arms and armour has been preserved in the museum collections or as yet been found during archaeological excavations.

There is one exception among the archaeological sites in this sense - it is the Ljubljanica River, which yielded an important array of medieval arms and armour, as well as riding and horse gear from the $11^{\text {th }}$ to the $15^{\text {th }}$ century (Fig. 19). There are more than 6000 finds of different kinds and of all periods, from prehistory onwards, kept in the National
Museum of Slovenia. Of these, the medieval arms and some pieces of armour are important sources of knowledge on arms and armed men in this part of Europe in the Middle Ages. They form the largest and most significant collection of its kind in Slovenia. Because of their excellent preservation, typological diversity and quantity, but also because of the exceptionality and rarity of individual categories and types, especially swords, the finds from the Ljubljanica are of great significance on a European scale as well (Fig. 21). They document not only the equipment of the medieval soldiers, but also the significance of arms and armour in various kinds of military activities that took place in the territory of Slovenia as a borderland in the Middle $\mathrm{Ages}^{40}$.

\section{Bibliography}

Altmann W. (ed.) 1893. Eberhart Windeckes Denkwürdigkeiten zur Geschichte des Zeitalters Kaiser Sigmunds. Berlin.

Bitenc P., Knific T. 2001. Od Rimljanov do Slovanov 3. Predmeti. Ljubljana.

Ciglenečki S. 1992. Pólis Norikón. Poznoantične višinske utrdbe med Celjem in Brežicami. Podsreda.

Dolinar F. M., Gabrič A., Golec B., Kosi M., Nabergoj T., Rihtaršič M. 2011. Slovenski zgodovinski atlas. Ljubljana.

Foulke W. D. (transl.) 1907. History of the Langobards by Paul the Deacon. Philadelphia.

Istenič J. 2006. The Roman Period. In: T. Nabergoj (ed.), Steps into the Past. Treasures from the archaeological collections of the National Museum of Slovenia. Ljubljana, 42-48.

Istenič J. 2015. Roman stories from the crossroads. Ljubljana.

Karo Š. 2012a. Oprema jahača i konja s Gradišča nad Bašljem (Slovenija). In: T. Šeparović (ed.), Dani Stjepana Gunjače 2. Zbornik radova sa znanstvenog skupa. Split, 297-315.

Karo Š. 2012b. Zgodnjekarolinške najdbe s slovenskih najdišč. In: I. Lazar, B. Županek (eds.), Emona med Akvilejo in Panonijo/Emona between Aquileia and Pannonia. Koper, 447-458.

Karo Š., Knific T. 2015. Gradišče above Bašelj in the early medieval Carniola (Slovenia). In: M. Gustin, D. Hall, E. Schellen (eds.), The legacy of Charlemagne: 814-2014. Gent, 285-296.

Karo Š., Knific T., Lubšina-Tušek M. 2011. Predmeti avarskega izvora z arheoloških najdišč v Sloveniji. „Vjesnik Arheološkog muzeja u Zagrebu" 44, 131-159.

Knific T. 1994. Tracce degli Unni in Slovenia? In: S. Blason Scarel (ed.), Attila Flagellum Dei?/Convegno internazionale di studi storici sulla figura di Attila e sulla discesa degli Unni in Italia nel 452 d.C. (1990, Udine). Studia historica 129. Roma, 48-68.

Knific T. 1995. Vojščaki iz mesta Karnija. „Kranjski zbornik”1995, 23-40.

Knific T. 2004. Prima dell'Italia: dati archeologici sui guerrieri longobardi in Slovenia. In: P. Moro (ed.), I Longobardi e la guerra. Da Alboino alla battaglia sulla Livenza. Roma, 124-143.

Knific T., Nabergoj T. 2016. Medieval Stories from the Crossroads. Ljubljana.

Knific T., Svoljšak D. 1984. Grobovi langobardskih vojščakov iz Solkana (Nova Gorica). „Arheološki vestnik” 35, $277-292$.

Kos P. 2015. Ad Pirum (Hrušica) e i Claustra Alpium Iuliarum. Ljubljana.

Kosi M. 1998. Potujoči srednji vek. Cesta, popotnik in promet na Slovenskem med antiko in 16. stoletjem. Zbirka ZRC 20. Ljubljana.

Kusetič J., Kos P., Breznik A., Stokin M. 2014. Claustra Alpium Iuliarum - med raziskovanjem in upravljanjem/Claustra Alpium Iuliarum - between research and management. Ljubljana.

Lazar T. 2009. Vojaška zgodovina slovenskega ozemlja od 13. do 15. stoletja (unpublished doctoral thesis). Ljubljana.

Lazar T. 2012. Vitezi, najemniki in smodnik. Vojskovanje na Slovenskem v poznem srednjem veku. Ljubljana.

Lazar T. 2015. Poznosrednjeveško topništvo na Slovenskem. Raziskave dveh zgodnjih topov iz Pokrajinskega muzeja Ptuj - Ormož/Late-Medieval Artillery in Slovenia. A Study of Two Early Artillery Pieces from the Regional Museum Ptuj - Ormož. Ljubljana.

Lazar T., Nabergoj T., Jerin B. (eds.) 2011. Vitez, dama in zmaj. Dediščina srednjeveških bojevnikov na Slovenskem 1: Razprave. Ljubljana.

40 Cf. Turk et al. 2009; Lazar et al. 2013. 
Lazar T., Nabergoj T., Bitenc P. (eds.) 2013. Vitez, dama in zmaj. Dediščina srednjeveških bojevnikov na Slovenskem 2: Katalog. Ljubljana.

Lubšina Tušek M. 2004. Izročilo preteklosti med Potrčevo in Volkmerjevo cesto na Ptuju. In: L. Šuligoj (ed.), Zbornik Splošne bolnišnice dr. Jožeta Potrča Ptuj 1874-2004. Ptuj, 73-79.

Luthar O. (ed.) 2013. The land Between. A History of Slovenia. Second, revised edition. Frankfurt am Main, Berlin, Bern, Bruxelles, New York, Oxford, Wien.

Mlinar J. 2005. Podoba Celjskih grofov v narativnih virih. Ljubljana.

Odar B. 2006. The archer from Carnium/Lokostrelec iz Karnija. „Arheološki vestnik” 57, 243-275.

Pleterski A. 1987. Sebenjski zaklad/Der Hortfund von Sebenje. „Arheološki vestnik” 31, 237-330.

Predovnik K., Nabergoj T. 2010. Archaeological research into the periods following the Early Middle Ages in Slovenia/ Arheološke raziskave obdobij po zgodnjem srednjem veku v Sloveniji. „Arheološki vestnik” 61, $245-294$.

Sagadin M., Pflaum V., Virag A., Milić Z., Lazar A. 2016. V blesku kovinske oprave. Poznoantična lamelna oklepa iz Kranja/Gleaming in armour. Late Antique lamellar armours from Kranj. Kranj.

Sitar S. 1989. Leonardovo Goriško jezero. „Kronika” 37, 169-172.

Šašel Kos M. 2009. The Ljubljanica and the myth of the Argonauts. In: P. Turk, J. Istenič, T. Knific, T. Nabergoj (eds.), The Ljubljanica - A River and its Past. Ljubljana, 120-124.

Turk P., Istenič J., Knific T., Nabergoj T. (eds.). 2009. The Ljubljanica - A River and its Past. Ljubljana.

Žargi M. 1993. Bitka pri Sisku 1593-1993. Ljubljana.

\section{Streszczenie}

\section{Ziemie Słowenii jako pogranicze w średniowieczu}

Położenie geograficzne między Morzem Adriatyckim, Alpami, Niziną Panońską i Półwyspem Bałkańskim od pradziejów czyniło z terytorium dzisiejszej Słowenii ważny region pograniczny. W szczególności dotyczyło to szlaku pomiędzy Półwyspem Apenińskim, zamkniętym od północy Alpami, a środkową i wschodnią lub południowo-wschodnią Europą. Położenie strategiczne i cechy krajobrazu określają pograniczną rolę względnie górzystego terytorium Słowenii. W regionie tym Nizina Panońska położona jest najbliżej Morza Śródziemnego, a przełęcze Krasu (szczególnie Brama Postojna), położone nie wyżej niż 606 m. n.p.m., zapewniają w miarę łatwe przejście między Półwyspem Apenińskim (Italią) a regionami śródlądowymi, jak dzisiejsze Węgry i Karyntia. Ważną rolę odgrywa też rzeka Ljubjanica, przepływająca przez Bagna Lublańskie i wpadająca do rzeki Sawy, która to z kolei jest dopływem Dunaju. Rzeka ta była istotną linią komunikacyjną od czasów prehistorycznych do późnego średniowiecza i początków okresu nowożytnego.

Terytorium dzisiejszej Słowenii miało bardzo ważne znaczenie dla Imperium Rzymskiego, strzegącego północnych granic Italii za pomocą alpejskiego systemu obrony. Pod koniec starożytności, w okresie stopniowego upadku Rzymu i rozprzestrzeniania się chrześcijaństwa, ziemie dzisiejszej Słowenii były świadkiem najazdów Gotów, Hunów i Longobardów na Italię. We wczesnym średniowieczu na terytorium tym zderzały się interesy Franków, Awarów i Bizantyjczyków, ponadto stopniowo osiedlali się tu Słowianie. Tworzyli oni swoją ojczyznę głównie wzdłuż doliny górnej Sawy - było to prawdopodobnie księstwo zwane Carniola Sclavorum partia pod koniec VIII wieku. Od początków IX w. mieszkańcy Krainy zmuszeni zostali do przyjęcia chrześcijaństwa i poddania się władzy Franków, którzy ostatecznie zniszczyli Kaganat Awarski. W pierwszej połowie X w. przez tereny te często przechodzili Węgrzy podczas swych najazdów na Włochy. Po ich pokonaniu, Królestwo Niemieckie utworzyło system obronny prowincji pogranicznych i wprowadziło nowy system gospodarczy i społeczny.

Rozwinięte i późne średniowiecze to czas tworzenia się majątków feudalnych, hrabstw i państw, a także rozwoju miast. W okresie tym ziemie słoweńskie dotykane były wielkimi kampaniami wojennymi. Działaniami militarnymi wywierającymi bezpośredni wpływ były kampanie Przemysła Otokara II około 1270 roku, walki między Habsburgami a hrabiami Cilli w latach 1437-1443 oraz wojny między Habsburgami a Wenecją pod koniec średniowiecza (1508-1516). W tym ostatnim okresie ziemie dzisiejszej Słowenii stały się pograniczem chroniącym przed Turcją Otomańską. Artykuł omawia niektóre z tych wydarzeń i przedstawia wybór zachowanych zabytków uzbrojenia, rzędu końskiego i oporządzenia jeździeckiego, przechowywanych w muzeach Słowenii. Omawia także szereg stanowisk archeologicznych. Wśród stanowisk z okresu późnej starożytności najważniejszymi są twierdza Hrušica (Ad Pirum), alpejski system obronny i cmentarzysko w Lajh w mieście Kranj, a także niektóre umocnione osady, jak Ajdovski gradec koło Vranje. Naważniejsze stanowiska średniowieczne to Sebenje koło Bled, gdzie znaleziony został skarb, czy umocniona osada w Gradišče koło Bašelj. Szczególną rolę odgrywa tu rzeka Ljubljanica, z której pochodzi największy i najważniejszy zbiór broni średniowiecznej oraz pewne zabytki zbroi ze Słowenii. 